Article

\title{
Parameterization of the Satellite-Based Model (METRIC) for the Estimation of Instantaneous Surface Energy Balance Components over a Drip-Irrigated Vineyard
}

\section{Marcos Carrasco-Benavides ${ }^{1}$, Samuel Ortega-Farías ${ }^{2, *}$, Luis Octavio Lagos ${ }^{3}$, Jan Kleissl ${ }^{4}$, Luis Morales-Salinas ${ }^{5}$ and Ayse Kilic ${ }^{6}$}

1 Departamento de Ciencias Agrarias, Universidad Católica del Maule, Curicó 3341695, Chile; E-Mail: mcarrascob@ucm.cl

2 Centro de Investigación y Transferencia en Riego y Agroclimatología (CITRA), Universidad de Talca, Talca 3460000, Chile

3 Centro de Recursos Hídricos para la Agricultura y la Minería, Universidad de Concepción, Chillán 3812120, Chile; E-Mail: octaviolagos@udec.cl

4 Department of Mechanical \& Aerospace Engineering, University of California, San Diego, CA 92093, USA; E-Mail: jkleissl@ucsd.edu

5 Laboratory for Research in Environmental Sciences (LARES), Faculty of Agricultural Sciences, University of Chile, Santiago 8820808,Chile; E-Mail: 1morales@renare.uchile.cl

6 School of Natural Resources and Civil Engineering, University of Nebraska-Lincoln, Lincoln, NE 68583, USA; E-Mail: kilic@unl.edu

* Author to whom correspondence should be addressed; E-Mail: sortega@utalca.cl; Tel.: +56-71-220-0426.

External Editors: Alfredo R. Huete and Prasad S. Thenkabail

Received: 30 May 2014; in revised form: 17 October 2014 / Accepted: 21 October 2014 / Published: 14 November 2014

Abstract: A study was carried out to parameterize the METRIC (Mapping EvapoTranspiration at high Resolution with Internalized Calibration) model for estimating instantaneous values of albedo (shortwave albedo) $\left(\alpha_{i}\right)$, net radiation $\left(R_{n i}\right)$ and soil heat flux $\left(G_{i}\right)$, sensible $\left(H_{i}\right)$ and latent heat $\left(L E_{i}\right)$ over a drip-irrigated Merlot vineyard (location: $35^{\circ} 25^{\prime} \mathrm{LS} ; 71^{\circ} 32^{\prime} \mathrm{LW} ; 125$ m.a.s. (1). The experiment was carried out in a plot of 4.25 ha, processing 15 Landsat images, which were acquired from 2006 to 2009. An automatic weather station was placed inside the experimental plot to measure $\alpha_{i}, R_{n i}$ and $G_{i}$. In the same tower an Eddy Covariance (EC) system was mounted to measure $H_{i}$ and $L E_{i}$. Specific 
sub-models to estimate $G$, leaf area index $(L A I)$ and aerodynamic roughness length for momentum transfer $\left(z_{o m}\right)$ were calibrated for the Merlot vineyard as an improvement to the original METRIC model. Results indicated that LAI, zom and $G_{i}$ were estimated using the calibrated functions with errors of $4 \%, 2 \%$ and $17 \%$, while those were computed using the original functions with errors of $58 \%, 81 \%$, and $5 \%$, respectively. At the time of satellite overpass, comparisons between measured and estimated values indicated that METRIC overestimated $\alpha_{i}$ in $21 \%$ and $R_{n i}$ in $11 \%$. Also, METRIC using the calibrated functions overestimated $H_{i}$ and $L E_{i}$ with errors of $16 \%$ and $17 \%$, respectively while it using the original functions overestimated $H_{i}$ and $L E_{i}$ with errors of $13 \%$ and $15 \%$, respectively. Finally, $L E_{i}$ was estimated with root mean square error (RMSE) between 43 and $60 \mathrm{~W} \cdot \mathrm{m}^{-2}$ and mean absolute error (MAE) between 35 and $48 \mathrm{~W} \cdot \mathrm{m}^{-2}$ for both calibrated and original functions, respectively. These results suggested that biases observed for instantaneous pixel-by-pixel values of $R_{n i}, G_{i}$ and other intermediate components of the algorithm were presumably absorbed into the computation of sensible heat flux as a result of the internal self-calibration of METRIC.

Keywords: evapotranspiration; soil heat flux; irrigation strategies; Merlot; albedo; leaf area index

\section{Appendix: Definition of Variables}

$\begin{array}{ll}\text { Symbol } & \text { Definition } \\ C f & \text { Ratio of turbulent fluxes to available energy or energy balance closure } \\ & \left(=(H+L E) /\left(R_{n}-G\right)\right)(\text { dimensionless }) \\ C_{p} & \text { Specific heat capacity of air }\left(1004 \mathrm{~J} \mathrm{~kg}^{-1} \cdot \mathrm{K}^{-1}\right) \\ d & \text { Zero plane displacement for heigth }(\mathrm{m}) \\ E T_{a} & \text { Actual evapotranspiration }\left(\mathrm{mm} \cdot \mathrm{d}^{-1}\right) \\ E T_{a} M & E T_{a} \text { computed for METRIC for each pixel }\left(\mathrm{mm} \cdot \mathrm{d}^{-1}\right) \\ E T_{i} & E T_{a} \text { at the instant of satellite overpass }\left(\mathrm{mm} \cdot \mathrm{h}^{-1}\right) \\ E T_{i_{-} M} & \text { Instantaneous } E T_{a} \text { calculated for METRIC for each pixel }\left(\mathrm{mm} \cdot \mathrm{h}^{-1}\right) \\ E T_{o} & \text { Penman-Montetith reference evapotranspiration computed for grass }\left(\mathrm{mm} \cdot \mathrm{d}^{-1}\right) \\ E T_{o_{-} i} & \text { Hourly reference evapotranspiration at the time of satellite overpass }\left(\mathrm{mm} \cdot \mathrm{h}^{-1}\right) \\ E T_{r} & \text { Reference evapotranspiration }(\text { for alfalfa })\left(\mathrm{mm} \cdot \mathrm{d}^{-1}\right) \\ f_{c} & \text { Fractional cover }(\text { fraction }) \\ F_{i_{-} M} & \text { Reference evapotranspiration fraction computed by METRIC at the time of satellite } \\ G & \text { Overpass }\left(=E T_{i} M / E T_{o h}\right)(\text { dimensionless }) \\ G & \text { Soil heat flux }\left(\mathrm{W} \cdot \mathrm{m}^{-2}\right) \\ G_{-} M & \text { Soil heat flux estimated by METRIC at the time of satellite overpass }\left(\mathrm{W} \cdot \mathrm{m}^{-2}\right) \\ G_{i} & \text { Soil heat flux at the instant of satellite overpass }\left(\mathrm{W} \cdot \mathrm{m}^{-2}\right) \\ H & \text { Sensible heat flux }\left(\mathrm{W} \cdot \mathrm{m}^{-2}\right) \\ H{ }_{-} M & \text { Sensible heat flux estimated by METRIC at the time of satellite overpass }\left(\mathrm{W} \cdot \mathrm{m}^{-2}\right)\end{array}$


$h_{c} \quad$ Canopy heigth $(\mathrm{m})$

$H_{\text {cold }} \quad$ Sensible heat flux at the instant of at the time of satellite overpass for the cold Pixel $\left(\mathrm{W} \cdot \mathrm{m}^{-2}\right)$

$H_{i} \quad$ Sensible heat flux at the instant of satellite overpass $\left(\mathrm{W} \cdot \mathrm{m}^{-2}\right)$

$H_{\beta} \quad$ Sensible heat flux forced to close the energy balance using the Bowen ratio $\left(\mathrm{W} \cdot \mathrm{m}^{-2}\right)$

LAI Leaf Area Index $\left(\mathrm{m}^{2} \cdot \mathrm{m}^{-2}\right)$

$L A I_{-} M \quad$ Leaf Area Index estimated by satellite scene at each pixel $\left(\mathrm{m}^{2} \cdot \mathrm{m}^{-2}\right)$

LE Sensible heat flux $\left(\mathrm{W} \cdot \mathrm{m}^{-2}\right)$

$L E_{-} M \quad$ Latent heat flux estimated by METRIC at the time of satellite overpass $\left(\mathrm{W} \cdot \mathrm{m}^{-2}\right)$

$L E_{i} \quad$ Sensible heat flux at the instant of at the time of satellite overpass $\left(\mathrm{W} \cdot \mathrm{m}^{-2}\right)$

$L E_{\beta} \quad$ Latent heat flux forced to close the energy balance using the Bowen ratio $\left(\mathrm{W} \cdot \mathrm{m}^{-2}\right)$

NDVI Normalized Difference Vegetation Index (dimensionless)

$q^{\prime} \quad$ Humidity $\left(\mathrm{kg} \cdot \mathrm{kg}^{-1}\right)$

$r_{a h} \quad$ Aerodynamic resistance to heat transport $\left(\mathrm{s} \cdot \mathrm{m}^{-1}\right)$

$\mathrm{RH}_{a_{-} o} \quad$ Relative humidity for a short reference surface (fescue grass) (\%)

$R_{L \uparrow} \quad$ Outgoing longwave radiation $\left(\mathrm{W} \cdot \mathrm{m}^{-2}\right)$

$R_{L \downarrow} \quad$ Incoming longwave radiation $\left(\mathrm{W} \cdot \mathrm{m}^{-2}\right)$

$R_{n} M \quad$ Net radiation estimated by METRIC at the time of satellite overpas $\left(\mathrm{W} \cdot \mathrm{m}^{-2}\right)$

$R_{\text {ncold }} \quad$ Net radiation flux at the instant of at the time of satellite overpass for the cold pixel $\left(\mathrm{W} \cdot \mathrm{m}^{-2}\right)$

$R_{n i} \quad$ Net radiation at the instant of satellite overpass $\left(\mathrm{W} \cdot \mathrm{m}^{-2}\right)$

$r_{s} \quad$ Row spacing (m)

$R_{s \downarrow} \quad$ Incoming shortwave radiation $\left(\mathrm{W} \cdot \mathrm{m}^{-2}\right)$

$R_{\text {sin }} \quad$ Measured incoming solar radiation radiation $\left(\mathrm{W} \cdot \mathrm{m}^{-2}\right)$

$R_{s i n \_o} \quad$ Incoming solar radiation in reference conditions (fescue grass) $\left(\mathrm{W} \mathrm{m}^{-2} \cdot \mathrm{h}^{-1}\right.$ )

$R_{S o} \quad$ Measured outgoing solar radiation radiation $\left(\mathrm{W} \cdot \mathrm{m}^{-2}\right)$

SAVI Soil Adjusted Vegetation Index (dimensionless)

$T \quad$ Instantaneous sonic temperature $\left({ }^{\circ} \mathrm{K}\right)$

$T_{a} \quad$ Air temperature over the vineyard (fescue grass) $\left({ }^{\circ} \mathrm{C}\right)$

$T_{a_{-} o} \quad$ Air temperature for short reference surface (fescue grass) $\left({ }^{\circ} \mathrm{C}\right)$

$T_{a z 1}$ and $T_{a z 2} \quad$ Near surface air temperature $\left({ }^{\circ} \mathrm{K}\right)$

$T_{s} \quad$ Surface radiometric temperature $\left({ }^{\circ} \mathrm{C}\right.$ or $\left.{ }^{\circ} \mathrm{K}\right)$

$T_{s i} \quad$ Instantaneous surface radiometric temperature calculated for each pixel $\left({ }^{\circ} \mathrm{C}\right.$ or $\left.{ }^{\circ} \mathrm{K}\right)$

u2 $\quad$ Mean wind speed at 2-m height in reference conditions (fescue grass) $\left(\mathrm{m} \cdot \mathrm{s}^{-1}\right)$

VPD Vapor pressure deficit $(\mathrm{kPa})$

$w^{\prime} \quad$ Wind speed $\left(\mathrm{m} \cdot \mathrm{s}^{-1}\right)$

wbd Weighting coefficient of the Landsat bands for calculating broad-band surface Albedo (dimensionless)

$z_{o m} \quad$ Aerodynamic roughness length for momentum transfer (m)

$z_{o m \_} M \quad$ Aerodynamic roughness length for momentum transfer computed by METRIC (m)

$\alpha \quad$ Surface albedo (dimensionless) 


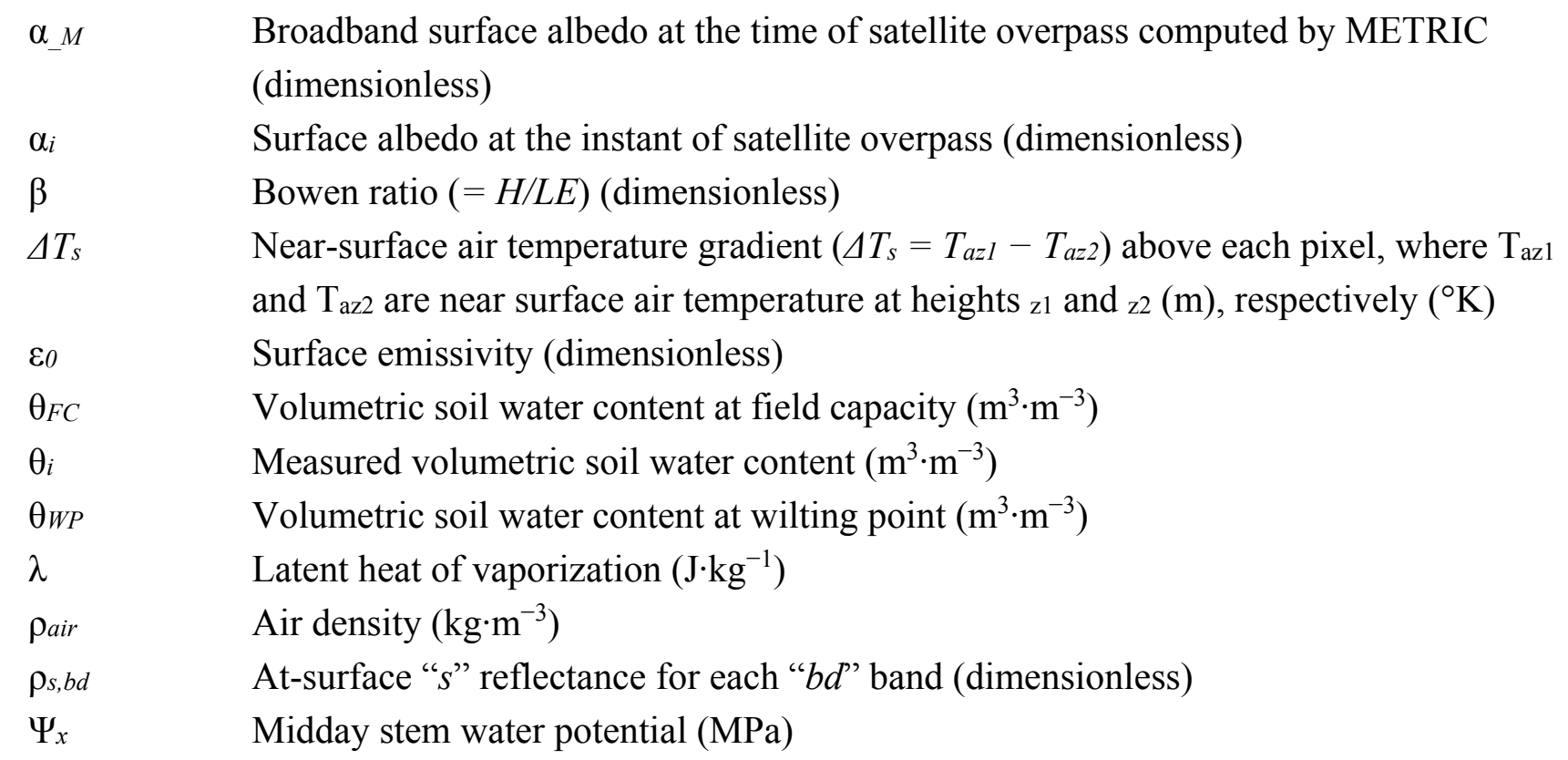

\section{Introduction}

Nowadays drip irrigated viticulture in semi-arid zones is under political and economic pressure to optimize irrigation strategies, considering the persistent diminishing water supply, due to increased consumption, mismanagement and pollution. In this regard, irrigation strategies such as regulated deficit irrigation or partial root drying have emerged as potential ways to increase water savings [1-3]. Therefore, it is critical to know the vineyard water use or actual evapotranspiration $\left(E T_{a}\right)$ during the entire growing season with the aim of planning and maintaining adequate water management [4-7]. Accurate estimation of $E T_{a}$ is a key to understand a range of hydrological, climatic, and ecosystem processes [8,9]. Presently, there are various methods to obtain $E T_{a}$ based on the measurements of the surface energy balance (SEB) [10,11] such as the Eddy Covariance (EC) and Bowen ratio (BRES) systems, which have been widely used in research to quantify $E T_{a}$ of a vineyard [7,12-17]. However, these systems do not provide spatial trends of $\mathrm{ET}_{\mathrm{a}}$ because these measurements represent a point influenced by a small footprint area $[18,19]$.

During the last 20 years, satellite-based remote sensing (SBRS) tools have emerged as a low-cost, yet reliable alternative to estimate $E T_{a}$ over large areas and wide range of vegetation types [10,11,20-24]. These remote sensing tools estimate $E T_{a}$ based on algorithms which compute the SEB components using remotely sensed surface reflectance in the visible $(V I S)$ and near-infrared $(N I R)$ wavebands and surface temperature (radiometric) from the infrared (IR) thermal bands [19,24,25]. In this manner, using satellite based data and ground-based weather measurements; $E T_{a}$ for each pixel is computed as a residual from the surface energy balance (RSEB) equation:

$$
\lambda E T_{i}=L E_{i}=R_{n i}-H_{i}-G_{i}
$$

where $\lambda$ is the latent heat of vaporization $\left(\mathrm{J} \cdot \mathrm{kg}^{-1}\right) ; E T_{i}$ is the instantaneous evapotranspiration $\left(\mathrm{mm} \cdot \mathrm{h}^{-1}\right) ; L E_{i}$ is latent heat flux $\left(\mathrm{W} \cdot \mathrm{m}^{-2}\right) ; R_{n i}$ is net radiation $\left(\mathrm{W} \cdot \mathrm{m}^{-2}\right) ; G_{i}$ is soil heat flux $\left(\mathrm{W} \cdot \mathrm{m}^{-2}\right)$ and $H_{i}$ is sensible heat flux $\left(\mathrm{W} \cdot \mathrm{m}^{-2}\right)$. Subscripts " $i$ " denote measurements at the time of satellite overpass. 
Most of the RSEB models available in the literature are one-source modeling approaches. One of the most cited algorithms is METRIC (Mapping EvapoTranspiration at high Resolution with Internalized Calibration) [26] which was derived from the SEBAL (Surface Energy Balance Algorithm for Lands) model [9]. SEBAL estimates the energy partitioning at a field scale using minimal requirements of field data over relatively flat landscapes with and without irrigation. As an improvement from SEBAL, METRIC was designed to estimate $E T_{a}$ for irrigated crops incorporating ground-based reference Penman-Monteith evapotranspiration by assuming a one-source resistance transfer scheme [22]. According to [27,28] the internal self-calibration of METRIC removes a substantial amount of systematic biases in the $E T_{a}$ estimate by calibrating the sensible heat flux for two extreme conditions (hot pixel and cold pixel) or "anchor pixels". Consequently, daily $E T_{a}$ can be obtained at high spatial resolution (e.g., $30 \mathrm{~m} \times 30 \mathrm{~m}$ for Landsat scenes) as follow:

$$
\begin{gathered}
E T_{a_{-} M}=E T_{o} \cdot F_{i_{-} M} \\
F_{i_{-} M}=\frac{E T_{i_{-} M}}{E T_{o_{-} i}}
\end{gathered}
$$

where $E T_{a_{-} M}$ is the daily $E T_{a}$ computed for each pixel $\left(\mathrm{mm} \cdot \mathrm{d}^{-1}\right) ; E T_{o}$ is the daily Penman-Monteith reference evapotranspiration $\left(\mathrm{mm} \cdot \mathrm{d}^{-1}\right)$ [29]; $F_{L_{-} M}$ is the reference evapotranspiration fraction developed from the near-instantaneous image time and assumed to be constant across the day for well-watered agricultural crops (dimensionless); $E T_{i_{-} M}$ is the instantaneous $E T_{a}$ computed for each pixel $\left(\mathrm{mm} \cdot \mathrm{h}^{-1}\right)$ [30-32]; $E T_{o_{-} i}$ is the instantaneous $E T_{o}\left(\mathrm{~mm} \cdot \mathrm{h}^{-1}\right)$.

According to [33] a disadvantage of the energy balance approach employed in METRIC is that the computation of the latent heat flux (and subsequently the estimated evapotranspiration) is only as accurate as the estimates of net radiation, soil heat flux and sensible heat flux. Several researchers have indicated that METRIC could present absolute errors between 5\% and 20\% in the estimation of daily or seasonal $E T_{a}$ of several fully covered crops such as alfalfa, bean, pea, potato, sugar beet, spring grain, winter grain, corn, soybean and sorghum [22,24,26,28,34]. On the other hand, the application of satellite-based models like METRIC to sparse crops such as vineyards has recently been applied with promising results [32,35-39]. Generally, vineyards have widely spaced rows that affect the partitioning and spatial distribution of net radiation. Thus, in a drip-irrigated vineyard, the partitioning of net radiation into sensible, latent and soil heat fluxes is conditioned to the surrounding soil, canopy training system and plant density, where the sensible heat flux is the principal component of the vineyard SEB [14,40]. Consequently, understanding the behavior of SEB components over drip-irrigated vineyard could provide insights into sources of error in the quantification of water and energy exchanges considering that canopies are geometrically and thermally heterogeneous. In this respect, [28] indicated that although daily values of SEB fluxes are generally more helpful and practical than instantaneous energy fluxes derived at the satellite overpass, it is important to identify the systematic model bias in the energy balance components on the image and attribute biases to correct the causes.

As far as we known, there are very few studies that evaluate the trends of SEB components over a drip-irrigated vineyard derived from remote-sensing techniques. Thus, it is necessary to evaluate the accuracy of RSEB models to estimate the energy balance components over sparse canopies such as vineyards. In this regard, the main goal of this research is to parameterize the METRIC model for 
estimating instantaneous values of $R_{n i}, G_{i}, H_{i}$ and $L E_{i}$ over a drip-irrigated Merlot vineyard under Mediterranean semi-arid climatic conditions. Also, the specific sub-models to estimate G, LAI and $z_{o m}$ were calibrated for the Merlot vineyard as an improvement of the original algorithm of METRIC.

\section{Theoretical Basis}

The instantaneous net radiation for each pixel at the time of the satellite overpass is estimated using the following equation:

$$
R_{n i}=\left(1-\alpha_{i}\right) \cdot R_{s \downarrow}+R_{L \downarrow}-R_{L \uparrow}-\left(1-\varepsilon_{0}\right) \cdot R_{L \downarrow}
$$

where $\alpha_{i}$ is the broadband surface albedo (dimensionless); $R_{s \downarrow}$ is the incoming shortwave radiation (W m ${ }^{-2}$ ); $R_{L \downarrow}$ and $R_{L \uparrow}$ are the incoming and outgoing longwave radiation, respectively and $\varepsilon_{o}$ is the surface emissivity that accounts for reflectance of incoming longwave radiation at the land surface [34]. The broadband albedo is computed by the integration of the surface reflectances for the visible and near infrared (NIR) bands using a weighting coefficient as [41]:

$$
\alpha_{i}=\sum_{b d=l}^{6}\left(\rho_{s, b d} \cdot w_{b d}\right)
$$

where $\rho_{s, b d}$ is at-surface " $s$ " reflectance for each " $b d$ " band (dimensionless) and $w b d$ is the weighting coefficient of the Landsat bands for calculating broad-band surface albedo (dimensionless).

To compute the instantaneous soil heat flux, three empirical relations depending on the leaf area index $(L A I)$ can be used. These functions were originally developed for annual crops as follows $[27,42]$.

$$
\begin{gathered}
\frac{G_{i}}{R_{n i}}=0.05+0.18 \cdot e^{-0.52 L A I} \quad(\text { if } \quad L A I \geq 0.5) \\
\frac{G_{i}}{R_{n i}}=1.8 \cdot \frac{T_{s i}}{R_{n i}}+0.84 \quad(\text { if } \quad L A I<0.5) \\
\frac{G_{i}}{R_{n i}}=T_{s} \cdot\left(c_{1} \alpha_{i}+c_{2}\right) \cdot(1-0.98 \cdot N D V I)
\end{gathered}
$$

where $T_{s i}$ is the radiometric temperature (in ${ }^{\circ} \mathrm{C}$ ) computed from the thermal infrared waveband (TIR); $L A I$ is expressed in $\left(\mathrm{m}^{2} \cdot \mathrm{m}^{-2}\right) ; 0.0074$ and 0.0038 are empirical coefficients and NDVI is the normalized difference vegetation index (dimensionless).

The leaf area index is computed in METRIC using the next empirical relations [27]:

$$
\begin{gathered}
L A I=11 \cdot S A V I^{3} \quad(\text { for } \quad S A V I \leq 0.817) \\
L A I=6 \quad(\text { for } \quad S A V I>0.817)
\end{gathered}
$$

where $S A V I$ is the soil adjusted vegetation index (dimensionless) [43] calculated for each pixel [42]. Instantaneous pixel-by-pixel sensible heat fluxes are obtained for each scene as follows:

$$
H_{i}=\frac{\rho_{a i r} \cdot C_{p} \cdot \Delta T_{s}}{r_{a h}}
$$

where $\rho_{\text {air }}$ is the air density $\left(\mathrm{kg} \cdot \mathrm{m}^{-3}\right) ; C_{p}$ is the specific heat capacity of air $\left(1004 \cdot \mathrm{J}^{\mathrm{kg}} \mathrm{kg}^{-1} \mathrm{~K}^{-1}\right) \cdot \Delta T_{s}$ is the near-surface air temperature gradient $\left(\Delta T_{s}=T_{a z 1}-T_{a z 2}\right)$ above each pixel, where $T_{a z 1}$ and $T_{a z 2}$ are near 
surface air temperature $\left({ }^{\circ} \mathrm{K}\right)$ at heights $z_{1}$ and $z_{2}$ above the elevation of $d+z_{o m}$, where $d$ is zero plane displacement height (all in $\mathrm{m}$ ). $r_{a h}$ is the aerodynamic resistance to heat transport $\left(\mathrm{s} \cdot \mathrm{m}^{-1}\right)$. Originally, METRIC estimates the values of $z_{\text {om }}$ based on the height $(h)$ of annual agricultural crops by assuming that the crop height vary proportionally with the $L A I$ [27]. Thus for agricultural areas, zom can be computed as follow:

$$
z_{\text {om }}=0.018 \cdot L A I
$$

Previous studies $[9,26]$ have demonstrated that $\Delta T_{s}$ can be spatially approximated as a simple linear function:

$$
\Delta T_{s}=\beta_{0}+\beta_{1} T_{s i}
$$

where $\beta_{0}$ and $\beta_{1}$ are empirical calibration coefficients for each satellite scene. $T_{s i}$ is expressed in ${ }^{\circ} \mathrm{K}$.

Considering that the values of $T_{a}$ above each pixel are unknown, the determination of $\beta_{0}$ and $\beta_{1}$ involves an iterative process, which is based in the selection of several well-known anchor pixels (wet and dry) at each scene. These anchor points are recognizable because they ideally represent the conditions of an agricultural field with full and active transpiration vegetation close to reference conditions (cold pixel) and a surface with no vegetation cover (hot pixel) with little or residual evaporation from soil [44]. In this manner, the SEB of the cold pixel can be computed as:

$$
H_{\text {cold }}=R_{\text {ncold }}-G_{\text {cold }}-\phi \cdot \lambda E T_{o_{-} i}
$$

where $H_{\text {cold }}, R_{\text {ncold }}$ and $G_{\text {cold }}$ represent the sensible heat, net radiation and soil heat fluxes for each cold pixel located inside the image at the time of satellite overpass $\left(\mathrm{W} \cdot \mathrm{m}^{-2}\right) ; \phi$ is an adjustment factor which incorporates the probability of wet soil surface beneath the vegetation canopy that may increase the total $E T_{o_{-} i}$ [30]. In the same way, the SEB of the hot pixel within each image can be calculated using the Equation (13), assuming that $E T_{o_{-} i}$ is near to zero.

In this manner, the values of $\beta_{0}$ and $\beta_{1}$ obtained from the anchor pixels are then used in the estimation of $H_{i}$ for each pixel by an iterative process that involves the Monin-Obukhov similarity theory $[22,25,26]$. The self-calibration of METRIC involves the inverse calibration of the SEB via the sensible heat flux computed by specifying the evapotranspiration at the two anchor pixels. This process removes systematic biases embedded in the estimations of $R_{n i}, G_{i}$ and other intermediate components of the METRIC algorithm, which are common to nearly all satellite-based calculations. These biases are in turn removed in the computation of the $E T_{a}$, considering that the process is executed for millions of pixels contained inside each scene [27]. For more details about METRIC data processing and physical-mathematical algorithms, refer to [26] and the METRIC application-manual [27].

\section{Materials and Methods}

The study was carried out in a drip-irrigated vineyard located in the Talca Valley, Maule Region, Chile (35 $25^{\prime} \mathrm{LS} ; 7^{\circ} 32^{\prime} \mathrm{LW}$; 125 m.a.s.l) during the 2006-2007, 2007-2008 and 2008-2009 growing seasons (Figure 1). The vineyard was planted in 1999 and it had a surface of 97 ha where approximately 57.3 ha are planted and the remainder is covered by buildings, roads, trees, gardens and a plant nursery. Inside the vineyard, a plot with Merlot vines (Vitis vinifera L.) of 4.25 ha was selected (Figure 2). This experimental plot was flat and surrounded by another vineyard field with similar 
characteristics. The climate of the area is classified as Mediterranean semiarid, with an annual mean temperature of $17.4{ }^{\circ} \mathrm{C}$. The minimum and maximum yearly temperatures are 8.2 and $22.3{ }^{\circ} \mathrm{C}$, respectively. Annual precipitation is around $700 \mathrm{~mm}$ concentrated in the fall and winter. The cumulative reference evapotranspiration is approximately $1100 \mathrm{~mm}$, from spring to summer. The soil type at the experimental plot is classified as Talca series (family Fine, mixed, thermic Ultic Haploxeralfs) with a clay loam texture. The volumetric soil content was measured as $0.36 \mathrm{~m}^{3} \cdot \mathrm{m}^{-3}(216 \mathrm{~mm})$ and $0.22 \mathrm{~m}^{3} \cdot \mathrm{m}^{-3}(132 \mathrm{~mm})$ for field capacity $\left(\theta_{F C}\right)$ and wilting point $\left(\theta_{W P}\right)$, respectively, considering a root depth of $0.6 \mathrm{~m}$. The maximum allowed depletion (MAD) of the soil was $174 \mathrm{~mm}$.

Figure 1. True color cropped image from Landsat 5 (TM) of the area of study (AOS) (image taken in 25 January 2008) (Universal Transverse Mercator-UTM 19, WGS 84, South). Red square indicates the vineyard allocation.

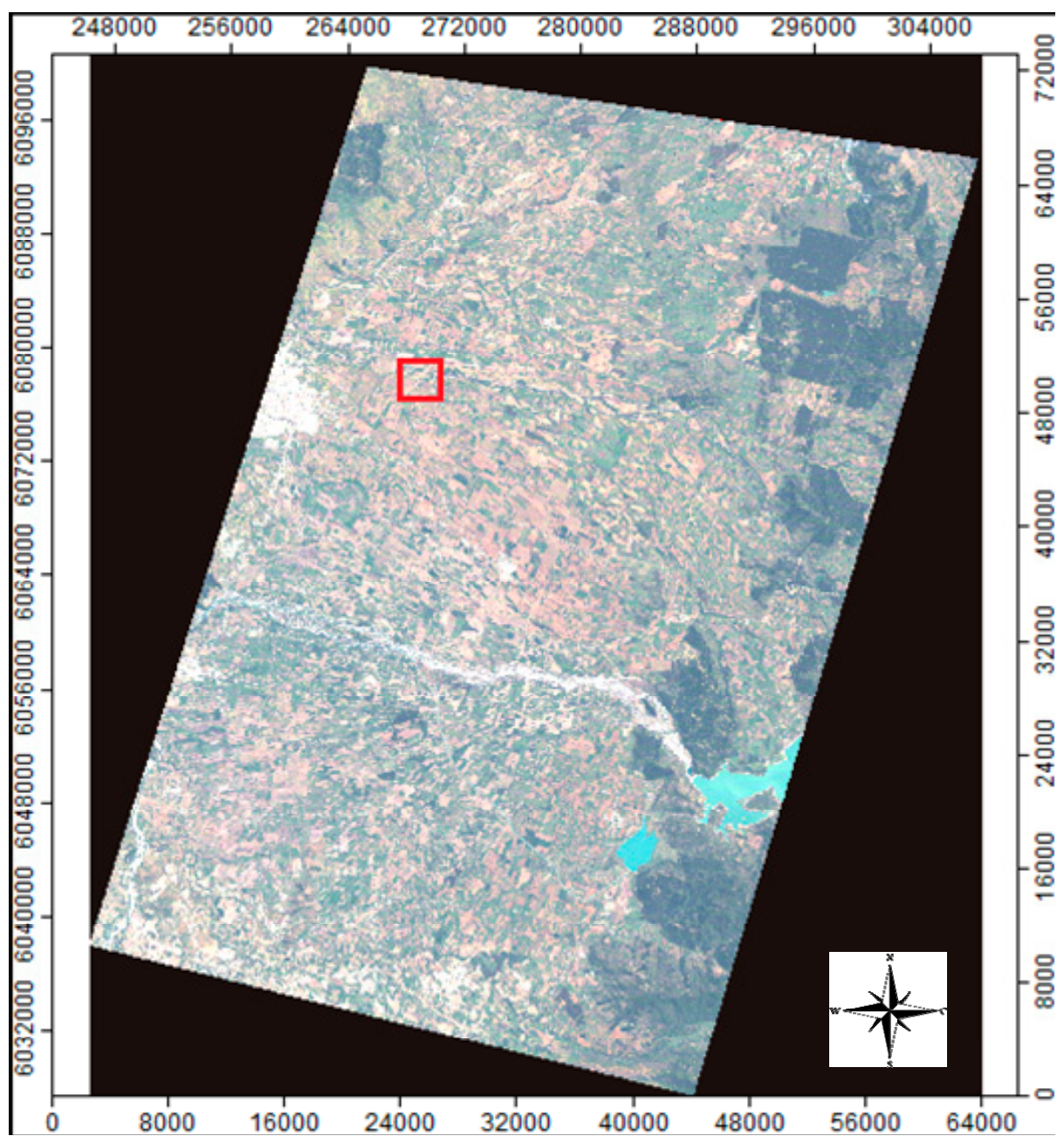


Figure 2. Site detail showing: (a) vine varieties distribution scheme; (b) image that shows the experimental plot (vineyard block $\mathrm{N}^{\circ} 22 \mathrm{~A}$ indicated as a segmented square). White dot inside the experimental plot indicates the Eddy Covariance system position; (c,d) show the analytical footprint model for all evaluated days under unstable conditions in terms of relative and cumulative contribution, respectively; (e) and (f) depict the wind-rose for unstable conditions at the peak (Xpeak) of the footprint function and during the time of satellite overpasses, respectively.
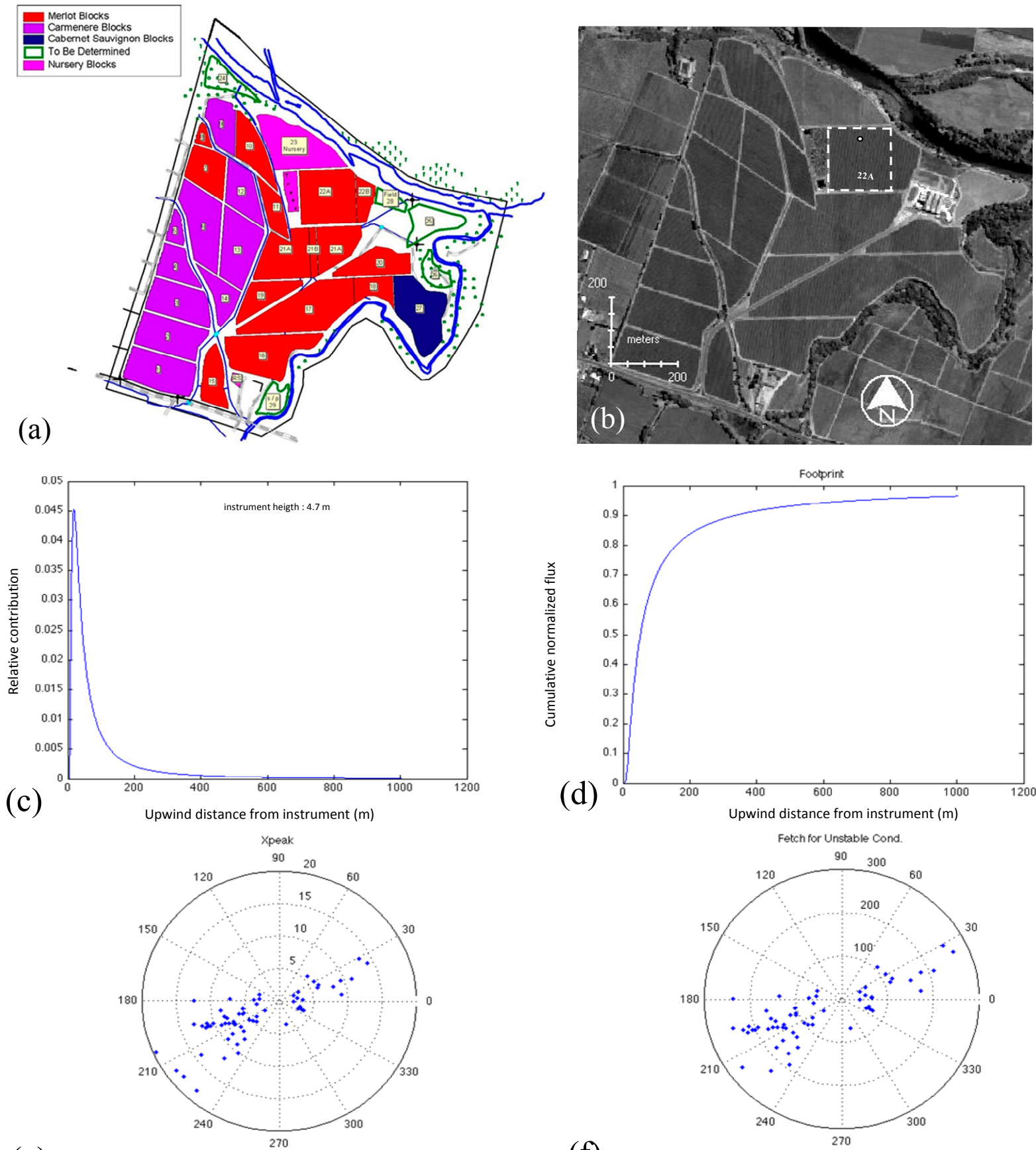

(e)

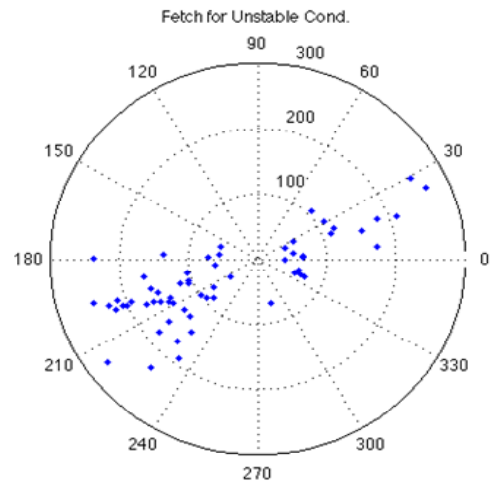

The training system of the Merlot vineyard was vertical shoot positioned (VSP) with a plant density of 2667 plants $\cdot \mathrm{ha}^{-1}$ (2.5 m between rows and $1.5 \mathrm{~m}$ between vines). The canopy width and foliage height were 0.5 and $2.0 \mathrm{~m}$, respectively. The canopy was maintained as a parallelepiped where the 
values of $L A I$ and fractional cover $\left(f_{c}\right)$ were between $0.8-1.2 \mathrm{~m}^{2} \cdot \mathrm{m}^{-2}$ and $0.28-0.31 \mathrm{~m}^{2} \cdot \mathrm{m}^{-2}$, respectively, particularly after bloom (about mid-November) by hedging two or three times during the summer. The vineyard was drip-irrigated using emitters of $4.0 \mathrm{~L} \cdot \mathrm{h}^{-1}$ spaced at $1.5 \mathrm{~m}$ along the rows. It is important to note that vines were maintained under non-water stress conditions during the study period. This condition was evaluated using weekly measurements of volumetric soil water content $\left(\theta_{i}\right)$ at the effective rooting depth and midday stem water potential $\left(\Psi_{x}\right)$. Measurements of $\theta_{i}$ and $\Psi_{x}$ were done using a portable Time Domain Reflectometry (TDR, Trase System, 6050X1, Santa Barbara CA, USA) and a pressure chamber (PMS instruments, model 600, Albany OR, USA), respectively. Five key phenological stages were identified according to [45]: Bud break (B), Flowering (FL), Fruit set (FS), Veraison (V) and Harvest (HA). Based on visual inspection, the start of a stage was assumed to occur when $50 \%$ of vines had reached a new phenological state.

\subsection{Vine Surface Energy Balance Measurements}

A tower of $4.7 \mathrm{~m}$ of height was installed over the Merlot vineyard to measure the meteorological variables and energy balance components. Height and sensor characteristics are indicated in Table 1. To measure the net radiation, incoming $\left(R_{s i n}\right)$ and outgoing solar radiation $\left(R_{s o}\right)$ a four-component net radiometer (Kipp\&Zonen Inc, CNR1, Delft, The Netherlands) was installed above the canopy. Values of $R_{s o}$ and $R_{s i n}$ were also used to compute the vineyard albedo $\left(\alpha=R_{s i n} / R_{s o}\right)$. Additionally as backup, a net radiometer (REBS, Q7.1, Seattle, WA, USA) was installed next to the tower at the same height. For the 2008-2009 seasons the four-component net radiometer was removed and the measurements continued using only the REBS Q7.1 net radiometer. Surface soil heat flux at $0.08 \mathrm{~m}$ depth was measured by eight soil heat flux plates (HFT3, Campbell Scientific Inc., Logan, UT, USA) regularly distributed along the space between the inter-row and inter-plant. Surface soil heat fluxes were computed by correcting the soil heat fluxes at $0.08 \mathrm{~m}$ using thermal storage computed from four pairs of soil temperature thermocouples (TCAV, Campbell Scientific Inc., Logan, UT, USA). These allowed the better integration of the higher values from the sun-exposed area and the lower values from the shadowed area considering the path of the sun from the morning to the afternoon.

Table 1. Sensor heights and configuration inside the experimental plot.

\begin{tabular}{|c|c|c|c|c|}
\hline Sensor & Manufacturer, Model & Quantity & Heigt (m) & Origin \\
\hline Four-component Net Radiometer & Kipp \& Zonen, CNR1 & 1 & 4.7 & Delft, The Netherlands \\
\hline Net Radiometer & REBS, Q7.1 & 1 & 4.7 & Washington, USA \\
\hline Soil heat flux plates & Campbell Scientific, HTF3 & 8 & -0.08 & Utah, USA \\
\hline Soil averaged temperature & Campbell Scientific, TCAV & 4 & -0.06 and -0.04 & Utah, USA \\
\hline Fast response open path Infrared Gas Analyzer & LI-COR Inc., LI-7500 & 1 & 4.7 & Nebraska, USA \\
\hline 3D Sonic anemometer & Campbell Scientific, CSAT3 & 1 & 4.7 & Utah, USA \\
\hline Wind speed and direction & Young, 03101-5 & 1 & 4.7 & Florida, USA \\
\hline Air temperature and relative humidity & Vaisala, HMP45C & 1 & 4.7 & Massachusetts, USA \\
\hline
\end{tabular}

Sensible and latent heat fluxes were measured using an Eddy Covariance system mounted at a height of $4.7 \mathrm{~m}$ (Table 1) and oriented towards the predominant wind direction (South). Sensible heat fluxes were calculated by a three-dimensional sonic anemometer/thermometer (CSAT 3, Campbell 
Scientific Inc., Logan, UT, USA) and latent heat fluxes were computed by a fast response open path infrared gas analyzer (IRGA) (LI-COR Inc., LI7500, Lincoln, NE, USA) as follows [46]:

$$
\begin{aligned}
& L E=\rho_{\text {air }} \cdot \lambda \cdot \overline{w^{\prime} q^{\prime}} \\
& H=C_{p} \cdot \rho_{\text {air }} \cdot \overline{w^{\prime} T^{\prime}}
\end{aligned}
$$

where $\overline{\mathrm{w}^{\prime} \mathrm{q}}$ is the covariance between the instantaneous variation of the vertical wind speed $\left(w^{\prime}\right)\left(\mathrm{m} \cdot \mathrm{s}^{-1}\right)$ and humidity $\left(q^{\prime}\right) \cdot\left(\mathrm{kg} \cdot \mathrm{kg}^{-1}\right) ; \overline{\mathrm{w}^{\prime} \mathrm{T}^{\prime}}$ is the covariance between $w^{\prime}$ and the instantaneous sonic temperature $\left(T^{\prime}\right)\left({ }^{\circ} \mathrm{K}\right)$.

The footprint analysis indicated that $90 \%$ of cumulative normalized fluxes were close to $550 \mathrm{~m}$ $(\mathrm{r} F R=117: 1)$ at the time of satellite overpass (Figure $2 \mathrm{c}, \mathrm{d})$. Also, the wind-rose from Figure 2e,f shows the existing upwind fetch of the prevailing wind direction (South). Raw data of $H$ and $L E$ were post-processed considering corrections of density [47], sonic temperature [48] and coordinate rotation [49]. These data were computed over $30 \mathrm{~min}$ intervals. For the quality control, the energy balance closure was computed using the ratio $\left(C_{f}\right)$ of turbulent fluxes $(H+L E)$ to available energy $\left(R_{n}-G\right)$. When the daily ratios were outside the range between 0.8 and 1.2 , the entire day was excluded to reduce the uncertainty associated with errors in the $L E$ and $H$ measurements [40]. Assuming that the measurements of $R_{n}$ and $G$ were representative of the available energy in the vineyard, the fluxes of $H$ and $L E$ were forced to close the energy balance using the Bowen ratio $[13,50,51]$ :

$$
L E_{\beta}=\frac{\left(R_{n}-G\right)}{(1+\beta)} ; \quad H_{\beta}=\frac{\left(R_{n}-G\right)}{\left(1+\beta^{-1}\right)}
$$

where $\beta(=H / L E)$ is the hourly Bowen ratio (dimensionless). Subscript $\beta$ indicates that the turbulent energy fluxes were forced to close the energy balance using the Bowen ratio.

Raw net radiation, CSAT, and IRGA data were sampled and stored in a datalogger at $10 \mathrm{~Hz}$ (CR5000, Campbell Scientific Inc., Logan, UT, USA). Data of the surface soil heat flux plates and soil temperature thermocouples were also sampled and stored in a separate datalogger (CR1000, Campbell Scientific Inc., Logan, UT, USA).

\subsection{Reference Evapotranspiration}

An automatic weather station (Adcon Telemetry, A733GSM/GPRS, Klosterneuburg, Austria) was installed over 1 ha of well-irrigated fescue grass to measure hourly variables of air temperature $\left(\mathrm{T}_{\mathrm{a}_{-} \mathrm{o}}\right)\left({ }^{\circ} \mathrm{C}\right)$, relative humidity $\left(R H_{a_{-} o}\right)(\%)$, wind speed $\left(u_{2}\right)\left(\mathrm{m} \cdot \mathrm{s}^{-1}\right)$ and solar radiation $\left(R_{\text {sin } \_o}\right)\left(\mathrm{W} \cdot \mathrm{m}^{-2}\right)$. This information was used to compute the reference evapotranspiration using the Penman-Monteith model [29]. The weather station was located at $6.7 \mathrm{~km}$ from the vineyard $\left(35^{\circ} 22^{\prime} \mathrm{LS} ; 71^{\circ} 35^{\prime} \mathrm{LW}\right.$; 124 m.a.s.1.).

\subsection{Ground Measurements of Vineyard Reflectance}

During the growing seasons 2007-2008, 2008-2009 and 2009-2010, weekly ground measurements of reflectance for the near infrared $(N I R)$ and red $(R)$ wavebands (similar to Landsat) were collected for 
the space occupied for the canopy (r) and the bare soil (br). These measurements were taken in 64 grid points regularly spaced at $20 \times 20 \mathrm{~m}^{2}$ inside the experimental plot as previously indicated by [52] The measurements of NIR and $R$ wavebands were done using a handheld multi-spectral radiometer (CropScan Inc., MSR16R, Rochester, MN, USA). During the 2008-2009 growing season a thermal infrared thermometer (Exergen Corporation, IRt/c.2-K80F/27C,Watertown, MA, USA) was acquired to measure the thermal infrared waveband. Both sensors were mounted on a $3 \mathrm{~m}$ pole. Measurements were conducted near the satellite overpass time and allowed to obtain $N D V I$ and $T_{s}$.

\subsection{Landsat Satellite Datasets and Image Processing}

Two Landsat 5 (TM) and thirteen Landsat 7 (+ETM) satellite scenes (Path 233, Row 85) were downloaded from USGS Glovis [53] (Table 2). Scenes used in this research considered only days with less than 30\% cloud cover. Additionally, taking into account that since 2003 the +ETM images have shown gaps owing to failures in the satellite scan line corrector (slc-off), only scenes without gaps at the experimental plot were processed (Table 2). Maps of the complete vineyard's surface energy balance components were drawn by using the same scenes aforementioned. All Landsat scenes used in this research were acquired including a default for the systematic radiometric and geometric corrections which consider ground control points and a Digital Elevation Model (DEM) for topographic accuracy standard terrain correction (Level 1T-precision and terrain correction) [54].

Table 2. Images selected for processing surface energy balances over a drip-irrigated Merlot vineyard.

\begin{tabular}{ccccc}
\hline Growing Season & Date (mm-dd-yy) & DOY $^{*}$ & Satellite & Overpass Time (Local Time) \\
\hline \multirow{2}{*}{$2006-2007$} & $12-29-2006$ & 363 & Landsat 7 ETM+ & $11: 24: 41$ \\
& $01-12-2007$ & 14 & Landsat 7 ETM+ & $11: 24: 41$ \\
\hline & $11-30-2007$ & 334 & Landsat 7 ETM+ & $11: 24: 47$ \\
& $12-16-2007$ & 350 & Landsat 7 ETM+ & $11: 24: 47$ \\
& $01-01-2008$ & 1 & Landsat 7 ETM+ & $11: 24: 49$ \\
$2007-2008$ & $01-17-2008$ & 17 & Landsat 7 ETM+ & $11: 24: 49$ \\
& $01-25-2008$ & 25 & Landsat 5 TM & $11: 25: 33$ \\
& $02-02-2008$ & 33 & Landsat 7 ETM+ & $11: 24: 47$ \\
& $02-18-2008$ & 49 & Landsat 7 ETM+ & $11: 24: 44$ \\
\hline \multirow{2}{*}{$2008-2009$} & $10-23-2008$ & 297 & Landsat 5 TM & $11: 18: 16$ \\
& $11-16-2008$ & 321 & Landsat 7 ETM+ & $11: 23: 38$ \\
& $12-02-2008$ & 337 & Landsat 7 ETM+ & $11: 23: 50$ \\
& $01-03-2009$ & 3 & Landsat 7 ETM+ & $11: 24: 06$ \\
& $02-20-2009$ & 51 & Landsat 7 ETM+ & $11: 24: 26$ \\
& $03-08-2009$ & 67 & Landsat 7 ETM+ & $11: 24: 34$ \\
\hline
\end{tabular}

* DOY $=$ day of the year following the calendar day.

An area of study (AOS) of approximately $2804.7 \mathrm{~km}^{2}$ was delimited from each satellite image (Figure 1) and several anchor pixels (cold/dry) were selected according to the method proposed in literature [27,42]. Following the selection criteria suggested by [27,42,55] several pairs of anchor pixels were used for each satellite scene. Cold pixels were located within well-known green areas 
inside the AOS. For hot pixels selection, several points were tested considering agricultural fields that were bare at the time of satellite overpass. Also, a spreadsheet with the two-stage slab model described in the FAO-56 manual [56] was applied to ensure the assumption that the $E T_{a}$ from the soil hot pixels candidates of each image were near zero. For each image, the sensible heat flux at the cold anchor pixel was defined as it was indicated in Equation (14). In this study, a value of $\phi=1.2$ (Equation (14)) was used to estimate the $H_{\text {cold }}$ considering that the ratio of reference evapotranspiration for alfalfa $\left(E T_{r}\right)$ to $E T_{o}$ ranges from 1.2 to $1.4[42,57]$.

\subsection{Calibration of LAI, zom and G functions}

It is acknowledged that originally the METRIC model was developed for annual crops and it may not apply well to sparse crops such as vineyards with low fractional cover and heterogeneous canopy. For this reason, $L A I, z_{o m}$ and $G$ functions were calibrated using ground data collected from the vineyard. In this regard, the estimation of $L A I$ was done using the Weibull function (determination coefficient $\left.\left(R^{2}\right)=0.85\right)$ :

$$
L A I_{-}{ }_{M}=1.2-3.08 e^{\left(-2013.35 N D V I^{6.41}\right)}
$$

where $L A I_{-} M$ is the Leaf Area Index modeled by satellite scene at each pixel $\left(\mathrm{m}^{2} \cdot \mathrm{m}^{-2}\right)$

This model was developed using values of $L A I$ obtained from an allometric correlation [5,58] and NDVI computed from the handheld multi-spectral radiometer. It is important to indicate that values of NDVI calculated from Landsat scenes were significantly similar to those obtained from the handheld multi-spectral radiometer $\left(R^{2}=0.99 ; M A E=0.03 ; R M S E=0.04\right)$. According to [59], the Weibull function provides good estimations of growth because it assumes a monotonically increasing sigmoid growth similar to biological systems. The flexibility of this function is attributable to the parameters showed in Equation (18): parameter 1.2 represents the upper asymptote defined as the average maximum measured LAI. The parameters 3.08 and 2013.35 are both empirical constants, which define the shape of the pattern of growth. The parameter 6.41 determines the inflexion point.

The Perrier function for estimating $z_{o m}$ has been suggested by other authors [27,38] as an alternative to compute $z_{\text {om }}$ in sparse crops such as vineyards. In this study, values of $z_{\text {om }}$ were estimated using the following calibrated function $\left(R^{2}=0.96\right)$ :

$$
z_{\text {om }}=\left(\left(1-\exp \left(\frac{-0.09 L A I}{2}\right)\right) \cdot \exp \left(\frac{-0.09 L A I}{2}\right)\right) \cdot h
$$

where $h$ is the canopy height $(\mathrm{m})$. In this regard, $[12,52,60]$ indicated that values of the roughness length represents between $3 \%$ and $10 \%$ of plant height $[12,52,60]$.

For soil heat flux, the calibration of Equation (8) was based on ground measurements of net radiation, soil heat flux and albedo. Also, values of $N D V I$ and radiometric temperature were obtained using the hand-held radiometer. In this case, the calibration Equation (8) results in $\left(R^{2}=0.89\right)$ :

$$
\frac{G_{i}}{R_{n i}}=T_{s i} \cdot\left(0.0059 \cdot \alpha_{i}+0.0034\right) \cdot\left(1-0.98 \cdot N D V I^{4}\right)
$$




\subsection{Statistical Comparison between Measured and Estimated Values}

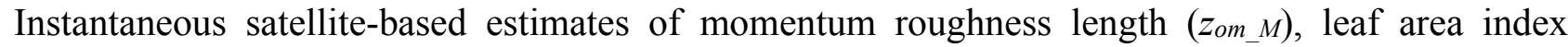
$\left(L A I_{-} M\right)$, albedo $\left(\alpha_{-} M\right)$, net radiation $\left(R_{n_{-}} M\right)$, soil heat flux $\left(G_{-} M\right)$, sensible heat flux $\left(H_{-} M\right)$, and latent heat flux $\left(L E_{-} M\right)$ were computed by averaging values of $36(30 \mathrm{~m} \times 30 \mathrm{~m})$ pixels that fell within the 4.25 ha experimental plot. To avoid the "contamination" caused by pixels outside the experimental plot a perimeter of $30 \mathrm{~m}$ from the edges inward was excluded when calculating field-scale averages SEB fluxes [9,34,61].

The validation of sub-models that compute the instantaneous energy balance components $\left(R_{n_{-} M}\right.$, $G_{-} M, H_{-} M$ and $\left.L E_{-} M\right), \alpha_{-} M, L A I_{-} M$ and $z_{o m_{-}} M$ was carried out using the ratio of estimated to observed values $(b)$, mean absolute error $(M A E)$, root-mean-square error (RMSE) and index of agreement $(d)$. The student's t-test analysis was applied to check whether $b$ was significantly different from unity at the $95 \%$ confidence level. For the validation, hourly measurements of $\alpha, R_{n}, G, H_{\beta}$ and $L E_{\beta}$ between 1100 and $1200 \mathrm{~h}$ were linearly interpolated to obtain the instantaneous values ( $\alpha_{i}, R_{n i}, G_{i}, H_{\beta i}$ and $\left.L E_{\beta i}\right)$ at the satellite overpass time (about $1125 \mathrm{~h}$ ). Values of MAE, RMSE and $d$ were respectively computed as follows [62-64]:

$$
\begin{aligned}
M A E & =\frac{\left(\sum\left|y_{i}-\hat{y}_{i}\right|\right)}{n} \\
R M S E & =\left(\frac{\left(\sum\left(y_{i}-\hat{y}_{i}\right)^{2}\right)}{n}\right)^{0.5}
\end{aligned}
$$

where $n$ is the number of pairs; $\mathrm{y}_{\mathrm{i}}$ and $\hat{\mathrm{y}}_{\mathrm{i}}$ are the observed and modeled values, respectively.

\section{Results and Discussion}

Generally the weather was hot and dry during the study period. Daily mean values of air temperature $\left(T_{a}\right)$ and vapor pressure deficit $(V P D)$ were $19.3{ }^{\circ} \mathrm{C}$ and $1.1 \mathrm{kPa}$, respectively. Maximum values of $T_{a}$ and $V P D$ were $35{ }^{\circ} \mathrm{C}$ and $4.1 \mathrm{kPa}$, respectively, which were reached near to $1800 \mathrm{~h}$. For this study, the volumetric soil water content at rooting depth ranged from 0.25 to $0.32 \mathrm{~m}^{3} \cdot \mathrm{m}^{-3}$ and mean $\Psi_{x}$ was between -0.4 and $-1.0 \mathrm{MPa}$ indicating that the Merlot vineyard was not under water stress during the three growing seasons [32,65-67].

The accuracy of the EC measurements above the vineyard was checked using the energy balance closure, which presented a coefficient of determination of 0.9 for the study period. Also, the hourly ratio of $(H+L E)$ to $\left(R_{n}-G\right)$ was equal to 0.9 indicating that the vineyard SEB was systematically imbalanced by about $10 \%$ [32]. On the other hand, Table 3 shows that the energy balance closure was $0.86( \pm 0.16)$ at the time of satellite overpass. According to [50], these uncertainties are modest and can be corrected using the Bowen-ratio approach $(\beta=H / L E)$. In this manner, the correction of the turbulent 
energy fluxes increased the hourly values of latent heat flux and sensible heat fluxes by about $4 \%$ and $6 \%$, respectively.

Table 3. Energy balance closure $\left(C_{f}\right)$, Bowen ratio $(\beta)$ and instantaneous ratios of latent $\left(L E_{\beta i}\right)$, sensible $\left(H_{\beta i}\right)$ and soil $\left(G_{i}\right)$ heat fluxes to net radiation $\left(R_{n i}\right)$ for a drip-irrigated vineyard at the satellite overpass. Instantaneous ratio of $R_{n i}$ to incoming solar radiation $\left(R_{\text {sin_}} i\right)$ is also included.

\begin{tabular}{|c|c|c|c|c|c|c|c|}
\hline Season & DOY & $C_{f}$ & $\boldsymbol{R}_{n i} / \boldsymbol{R}_{\text {sin } \_i}$ & $\boldsymbol{\beta}$ & $\boldsymbol{H}_{\beta i} / \boldsymbol{R}_{n i}$ & $L E_{\beta i} / R_{n i}$ & $\boldsymbol{G}_{i} / \boldsymbol{R}_{n i}$ \\
\hline \multirow{2}{*}{ 2006-2007 } & 363 & 1.09 & 0.68 & 0.91 & 0.37 & 0.41 & 0.22 \\
\hline & 14 & 0.80 & 0.67 & 1.24 & 0.44 & 0.36 & 0.22 \\
\hline \multirow{7}{*}{$2007-2008$} & 334 & 0.84 & 0.56 & 1.90 & 0.52 & 0.27 & 0.21 \\
\hline & 350 & 0.61 & 0.63 & 1.25 & 0.43 & 0.35 & 0.22 \\
\hline & 1 & 0.88 & 0.58 & 1.09 & 0.41 & 0.38 & 0.21 \\
\hline & 17 & 0.96 & 0.65 & 1.16 & 0.43 & 0.37 & 0.20 \\
\hline & 25 & 0.78 & 0.68 & 1.49 & 0.48 & 0.32 & 0.20 \\
\hline & 33 & 0.68 & 0.68 & 0.99 & 0.39 & 0.39 & 0.21 \\
\hline & 49 & 1.01 & 0.76 & 1.18 & 0.41 & 0.35 & 0.24 \\
\hline \multirow{8}{*}{ 2008-2009 } & 297 & 0.76 & 0.66 & 3.17 & 0.63 & 0.20 & 0.17 \\
\hline & 321 & 1.11 & 0.68 & 1.47 & 0.37 & 0.25 & 0.38 \\
\hline & 337 & 0.66 & 0.74 & 1.48 & 0.5 & 0.34 & 0.16 \\
\hline & 3 & 0.85 & 0.73 & 0.68 & 0.3 & 0.44 & 0.25 \\
\hline & 51 & 1.08 & 0.71 & 1.89 & 0.48 & 0.25 & 0.27 \\
\hline & 67 & 0.76 & 0.7 & 1.66 & 0.47 & 0.29 & 0.24 \\
\hline & Average & 0.86 & 0.67 & 1.44 & 0.44 & 0.33 & 0.23 \\
\hline & St. Dev. & 0.16 & 0.05 & 0.59 & 0.08 & 0.07 & 0.05 \\
\hline
\end{tabular}

Where DOY is the day of the year. Subscript " $i$ " denotes instantaneous values and subscript " $\beta$ " denotes that the fluxes were corrected using the Bowen-ratio approach.

The hourly variation of the albedo, Bowen ratio, $R_{n}, G, H_{\beta}$ and $L E_{\beta}$ over the Merlot vineyard is presented in Figure 3. During early morning, hourly values of albedo were close to 0.4 and decreased gradually reaching an almost constant value between 1000 and $1800 \mathrm{~h}$ with a mean $\alpha$ of $0.19( \pm 0.05)$ (Figure 3a). After $1800 \mathrm{~h}$, hourly albedo increased reaching values similar to those observed during early morning. At the time of satellite overpass, the measured albedo ranged from 0.12 to 0.18 for the drip-irrigated Merlot vineyard, which presented a ratio of vine row spacing $\left(r_{s}\right)$ to canopy height $\left(h_{c}\right)$ equal to 1.25 . Using $r_{s} / h_{c}=1.6$, the model of [68] estimated hourly albedos ranging between 0.18 and 0.2 for a vertical trellis system.

The diurnal variation of the Bowen ratio at the experimental plot is indicated in Figure $3 \mathrm{~b}$, which shows that hourly $\beta$ described an almost parabolic trend skewed to the left. At the time of satellite overpass, $\beta$ varied between 0.68 and 3.17 for the dataset (Table 3). Similar results were found by [69] who indicated that hourly $\beta$ was between 1.25 and 0.62 for a drip-irrigated vineyard cv. Sultana trained on a T-trellis system $\left(r_{s}=3.3 \mathrm{~m}, f_{c}=0.3-0.5\right)$. [46] for irrigated grapevines $\left(h_{c}=1.5 \mathrm{~m}, r_{s}=2.9 \mathrm{~m}\right)$ pointed out that hourly $\beta$ described an almost parabolic trend during the daytime where hourly $\beta$ ranged from 0.3 to 0.75 during 1000-1700 h. Also, [70] observed values of hourly Bowen ratio 
between 0.2 and 0.7 during the daytime for sunny days in table grapes cv. Niagara rosada trained on vertical shoot positioned system $\left(h_{c}=1.5 \mathrm{~m}, r_{s}=2.0 \mathrm{~m}\right)$.

Figure 3. Hourly variation of albedo $(\alpha)$, Bowen ratio $(\beta)$, net radiation $\left(R_{n}\right)$, soil heat flux $(G)$, sensible heat flux $\left(H_{\beta}\right)$ and latent heat flux $\left(L E_{\beta}\right)$ measured above a drip-irrigated vineyard for the days when satellite scenes were available. Dotted rectangles denote the satellite overpass hour (about 1124 h). Subscript " $\beta$ " denotes that the fluxes were corrected using the Bowen-ratio approach.
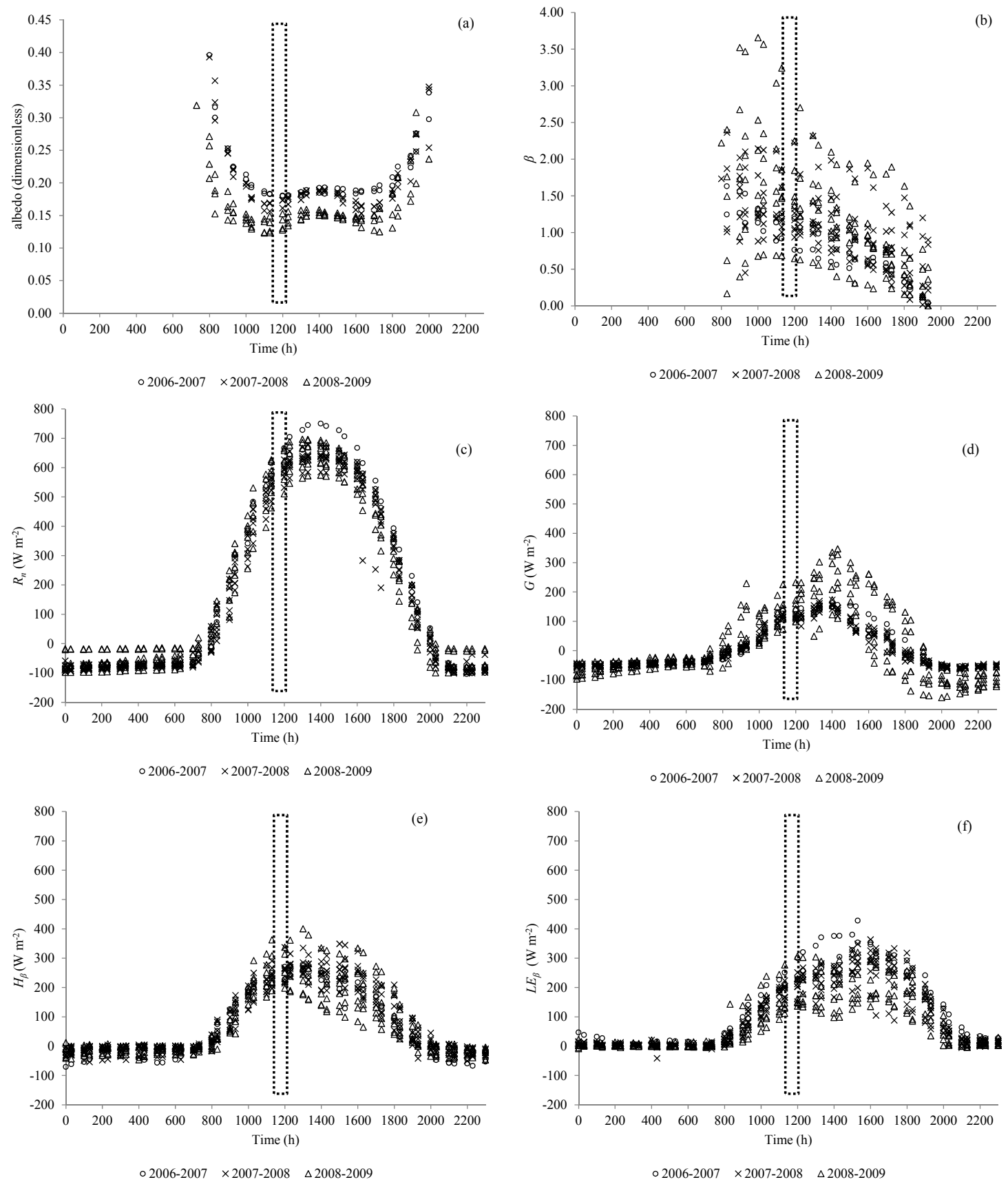

Figure $3 \mathrm{c}$ shows that the net radiation describes a bell shaped pattern where hourly fluxes increased during the morning until reaching a peak of $650( \pm 44) \mathrm{W} \cdot \mathrm{m}^{-2}$ at $1400 \mathrm{~h}$. Then, $R_{n}$ decreased gradually reaching values close to zero at $2000 \mathrm{~h}$. Similar patterns and values of $R_{n}$ were described in previous 
studies for vineyards $[14,16,70-73]$. For this study, mean ratio of $R_{n i}$ to instantaneous solar radiation $\left(R_{s i}\right)$ was $0.67( \pm 0.05)$ at the time of satellite overpass (Table 3$)$.

The hourly $G$ followed a curve skewed to the right, in comparison with the shape of $R_{n}$ (Figure $3 \mathrm{~d}$ ), starting at $800 \mathrm{~h}$ with values close to $-100 \mathrm{~W} \cdot \mathrm{m}^{-2}$ and reaching at $1500 \mathrm{~h}$ maximum values between 100 and $400 \mathrm{~W} \cdot \mathrm{m}^{-2}$. These trends could be associated to the row orientation, canopy architecture and the soil dampness effect on the surface temperature. For the daytime (between 800 and $1800 \mathrm{~h}$ ), the mean values of soil heat flux were $2.6( \pm 3) \mathrm{MJ} \cdot \mathrm{m}^{-2} \cdot \mathrm{d}^{-1}$ which was larger than those observed by [69] $\left(1.28 \mathrm{MJ} \cdot \mathrm{m}^{-2} \cdot \mathrm{d}^{-1}\right)$. For our study, values of $G$ accounted for $11 \%-37 \%$ of $R_{n}$ during daytime (data not shown). For this period, [12] indicated that $G$ accounted for as much as $38 \%-44 \%$ of $R_{n}$ for a drip irrigated Cabernet Sauvignon vineyard. Our results also differed from [7,16,69,74] who indicated that mean values of $G$ accounted for $11 \%-29 \%, 7 \%-11 \%, 5 \%-8 \%$ and $9 \%-11 \%$ of net radiation, respectively. Differences aforementioned presumably were due to differences in canopy geometry, plant density, and the number of sensors used to compute $G$. Instantaneous values of $G_{i}$ averaged $123( \pm 31) \mathrm{W} \cdot \mathrm{m}^{-2}$ (Figure $3 \mathrm{~d}$ ) accounting for $16 \%-38 \%$ of $R_{n i}$.

Hourly $H$ was small in the morning and increased near solar noon, reaching its maximum close to $400 \mathrm{~W} \mathrm{~m}^{-2}$ between 1400 and $1500 \mathrm{~h}$ (Figure 3e). [16,70,73] found hourly maximum values of $H$ between 300-400, 200-300 and 100-200 $\mathrm{W} \cdot \mathrm{m}^{-2}$, respectively. In our experiment, daytime $H_{\beta}$ accounting for $22 \%-60 \%$ of $R_{n}$ while [12,69] indicated that $H$ accounted for $25 \%-48 \%$ of $R_{n}$. Additionally, $H_{\beta i}$ ranged between 185 and $330 \mathrm{~W} \cdot \mathrm{m}^{-2}$ at the satellite overpass (Figure $3 \mathrm{e}$ ). Ratios of $H_{\beta i}$ to $R_{n i}$, were between 0.30 and 0.63 at about $1130 \mathrm{~h}$, indicating that almost half of the available energy of the vineyard was dissipated into sensible heat flux at the time of satellite overpass.

Hourly value of $L E_{\beta}$ increased smoothly from $800 \mathrm{~h}$ reaching its peak $\left(400 \mathrm{~W} \cdot \mathrm{m}^{-2}\right)$ between 1500 and $1600 \mathrm{~h}$ (Figure 3f). Daytime ratio of $L E_{\beta}$ to $R_{n}$ was between 0.22 and 0.52 while the instantaneous ratio of $L E_{\beta i}$ to $R_{n i}$ was between 0.20 and 0.44 . In general, results indicated that $L E_{\beta}$ was smaller than $H_{\beta}$ showing consistent results in comparison to previous studies carried out in a drip irrigated vineyard in the same path-row area [12] where $L E$ accounted for $20 \%-40 \%$ of $R_{n}$. In this regard [69] for a drip irrigated Sultana vineyard conducted on T-trellis system $\left(f_{c}=0.4 \pm 0.1\right)$ reported that the daytime ratio of $L E / R_{n}$ increased from 0.43 in warm-dry periods to 0.57 in cool-humid periods. For a drip irrigated Chardonnay vineyard training on a bilateral cordon trellis, [74] indicated that the ratios of $L E$ and $H$ to $R_{n}$ ranged between $0.46-0.67$ and $0.13-0.37$, respectively, concluding that the canopy architecture may have a substantial effect on soil and canopy energy balance, mainly by changing the partitioning of vineyard net irradiance into its soil and canopy components. Finally, [75] for agricultural and natural areas suggested that the partitioning of available energy is affected by water availability and vegetation cover. In our case, as aforementioned a constant shape of the canopy (a parallelepiped) was maintained without weeds between rows with $L A I$ ranging between 0.8 and $1.2 \mathrm{~m}^{2} \cdot \mathrm{m}^{-2}$ and $f_{c}$ values of $0.3( \pm 0.02)$ during the complete evaluated periods, especially after full bloom. Also, during these seasons, the top layer of soil $(0-20 \mathrm{~cm})$ in the inter-rows was very dry and soil surface wetted by drip emitters was $3 \%$. Under these canopy and soil water conditions, the soil contribution to the vineyard energy balance was considerable, especially under high atmospheric demand for water vapor. Under these conditions, sensible heat flux generated at the soil surface could be a major contributor to the vineyard energy balance which plays a key role in vine transpiration and evaporation [40]. 


\section{Comparison between Measured and Estimated Variables}

Results showed that the Weibull model (Equation (18)) estimated $L A I$ with values of $M A E=0.2 \mathrm{~m}^{2} \cdot \mathrm{m}^{-2}$ and $R M S E=0.3 \mathrm{~m}^{2} \cdot \mathrm{m}^{-2}$ (Table $4 \mathrm{a}$ ). Also, the t-test indicated that $b$ was significantly equal to unity indicating that estimated and observed values of $L A I$ were similar. In contrast, the original approaches (Equations (9) and (10)) underestimated LAI by about in 58\% with values of RMSE and MAE both equal to $0.6 \mathrm{~m}^{2} \cdot \mathrm{m}^{-2}$ (Table $4 \mathrm{~b}$ ). The good results obtained with the Weibull model can be associated to the constant shape of the canopy (a parallelepiped) that was maintained with $f_{c}$ values of $0.3( \pm 0.04)$ during the study period, especially after full bloom. Also, the soil surface was kept without weeds, because the top layer of soil $(0-20 \mathrm{~cm})$ was very dry and soil surface wetted by drip emitters was $3 \%$. Under these constant shape and soil water conditions, NDVI may be a valid input to estimate $L A I$, allowing a good performance of the Weibull model. In this manner, NDVI was selected because of its simplicity and robustness against other vegetation indices based on similar studies carried out on vineyards [76,77]. On the other hand, [77] indicated that the use of NDVI computed from images of low-spatial-resolution such as Landsat (pixel resolution: $900 \mathrm{~m}^{2}$ ) could generate poor estimations of $L A I$ because pixels contain mixed pixels reflectance information from the surface occupied by plants (row) and the between row space. Recently, in two vineyards, [58] indicated that the LAI can be overestimated up to $17 \%$ when contrasting geo-referenced $L A I$ data from cover photography method against NDVI obtained from the satellite World-View 2 (pixels resolution: $2 \mathrm{~m}^{2}$ ).

Table 4. Validation of sub-models that compute the instantaneous values of energy balance components, albedo, leaf area index and momentum roughness length for a drip-irrigated Merlot vineyard.

\begin{tabular}{|c|c|c|c|c|c|}
\hline (a) & \multicolumn{5}{|c|}{ Comparisons Using the Calibrated Function of $L A I, z_{o m}$ and $G$} \\
\hline Variable & RMSE & $M A E$ & $b$ & $d$ & t-Test \\
\hline LAI vs. $L A I_{-} M$ & $0.3\left(\mathrm{~m}^{2} \cdot \mathrm{m}^{-2}\right)$ & $0.2\left(\mathrm{~m}^{2} \cdot \mathrm{m}^{-2}\right)$ & 1.04 & 0.30 & $\mathrm{~T}$ \\
\hline $\mathrm{Z}_{\text {omi }} v s . z_{\text {om_M }} M$ & $0.01(\mathrm{~m})$ & $0.01(\mathrm{~m})$ & 0.98 & 0.64 & $\mathrm{~T}$ \\
\hline$R_{n i} v s . R_{n_{-} M}$ & $69\left(\mathrm{~W} \cdot \mathrm{m}^{-2}\right)$ & $63\left(\mathrm{~W} \cdot \mathrm{m}^{-2}\right)$ & 1.11 & 0.60 & $\mathrm{~F}$ \\
\hline$G_{i}$ vs. $G_{-M}$ & $34\left(\mathrm{~W} \cdot \mathrm{m}^{-2}\right)$ & $21\left(\mathrm{~W} \cdot \mathrm{m}^{-2}\right)$ & 0.83 & 0.39 & $\mathrm{~F}$ \\
\hline$H_{\beta i} v s . H_{-} M$ & $67\left(\mathrm{~W} \cdot \mathrm{m}^{-2}\right)$ & $57\left(\mathrm{~W} \cdot \mathrm{m}^{-2}\right)$ & 1.16 & 0.52 & $\mathrm{~F}$ \\
\hline$L E_{\beta i} v s . L \bar{E}_{-} M$ & $60\left(\mathrm{~W} \cdot \mathrm{m}^{-2}\right)$ & $48\left(\mathrm{~W} \cdot \mathrm{m}^{-2}\right)$ & 1.17 & 0.67 & $\mathrm{~F}$ \\
\hline (b) & \multicolumn{5}{|c|}{ Comparisons Using Original Function of LAI, $\mathrm{z}_{\mathrm{om}}$ and $\mathrm{G}$ [27] } \\
\hline Variable & RMSE & $M A E$ & $\boldsymbol{b}$ & $d$ & t-Test \\
\hline$L A I$ vs. $L A I_{-} M$ & $0.6\left(\mathrm{~m}^{2} \cdot \mathrm{m}^{-2}\right)$ & $0.6\left(\mathrm{~m}^{2} \cdot \mathrm{m}^{-2}\right)$ & 0.42 & 0.30 & $\mathrm{~F}$ \\
\hline$z_{\text {omi }} v s . z_{\text {om_M }} M$ & $0.08(\mathrm{~m})$ & $0.08(\mathrm{~m})$ & 0.19 & 0.50 & $\mathrm{~F}$ \\
\hline$\alpha_{i} v s . \alpha_{-} M$ & 0.04 & 0.04 & 0.79 & 0.28 & $\mathrm{~F}$ \\
\hline$R_{n i}$ vs. $R_{n_{-} M}$ & $70\left(\mathrm{~W} \cdot \mathrm{m}^{-2}\right)$ & $64\left(\mathrm{~W} \cdot \mathrm{m}^{-2}\right)$ & 1.11 & 0.60 & $\mathrm{~F}$ \\
\hline$G_{i}$ vs. $G_{-} M$ & $33\left(\mathrm{~W} \cdot \mathrm{m}^{-2}\right)$ & $26.3\left(\mathrm{~W} \cdot \mathrm{m}^{-2}\right)$ & 0.95 & 0.30 & $\mathrm{~T}$ \\
\hline$H_{\beta i} v s . \bar{H}_{-} M$ & $51\left(\mathrm{~W} \cdot \mathrm{m}^{-2}\right)$ & $43\left(\mathrm{~W} \cdot \mathrm{m}^{-2}\right)$ & 1.13 & 0.68 & $\mathrm{~F}$ \\
\hline$L E_{\beta i} v s . L \bar{E}_{-} M$ & $43\left(\mathrm{~W} \cdot \mathrm{m}^{-2}\right)$ & $35\left(\mathrm{~W} \cdot \mathrm{m}^{-2}\right)$ & 1.15 & 0.81 & $\mathrm{~F}$ \\
\hline \multicolumn{6}{|c|}{$\begin{array}{l}L A I=\text { leaf area index; } z_{o m}=\text { momentum roughness length; } \alpha=\text { surface albedo; } R_{n}=\text { net radiation; } G=\text { soil } \\
\text { heat flux; } H=\text { sensible heat flux and } L E=\text { latent heat flux. Sub indexes " } i \text { " denotes instantaneous ground } \\
\text { measured values, " } \beta \text { " denotes that the fluxes were corrected using the Bowen-ratio approach and " } M \text { " denotes } \\
\text { modeled values using METRIC. } R M S E=\text { root mean square error; } M A E=\text { mean absolute error; } b=\text { ratio of } \\
\text { observed to computed values; } d=\text { index of agreement; } \mathrm{T}=\text { null hypothesis }(b=1) \text { True; } \mathrm{F}=\text { alternative } \\
\text { hypothesis }(b \neq 1) \text { False. }\end{array}$} \\
\hline
\end{tabular}


Vineyard satellite-based estimations of $z_{o m}$ using the Perrier function (Equation (19)) generated $z_{o m}$ values ranging between 0.05 and $0.11 \mathrm{~m}$, which are within the values indicated by [12,60]. Validation analysis indicated that RMSE and MAE where both equal to $0.01 \mathrm{~m}$ (Table 4a). Also, $b$ was significantly equal to unity suggesting that estimated and observed values of $z_{o m}$ were similar. The original function (Equation (12)) used in METRIC algorithm [27] underestimated $z_{\text {om }}$ by about $81 \%$ with RMSE and MAE both equal to $0.08 \mathrm{~m}$ (Table $4 \mathrm{~b}$ ). These results suggest that canopy shape and $r_{s} / h_{c}$ ratio can plays a key role in the parameterization of $z_{o m}$.

For the albedo, the statistical t-test indicated that the ratio of estimated to observed values were significantly different from the unity indicating an underestimation of $21 \%$ (Table $4 \mathrm{~b}$ ). In this case, the values of $M A E$ and $R M S E$ were both equal to 0.04 . For the drip-irrigated vineyard, mean value of $\alpha_{i}$ was $0.2( \pm 0.13)$ while that of $\alpha_{-} M$ was $0.13( \pm 0.02)$. [35] indicated an albedo of 0.2 for seven sites corresponding to rainfed vineyards, which presented similar trellis structure as our experiment $\left(r_{s}=2.5 \mathrm{~m}, h_{c}=1.5 \mathrm{~m}\right)$. For a non-irrigated vineyard (cv. Airen) trained on free standing bushes $\left(f_{c}=0.3, h_{c}=0.9 \mathrm{~m}, r_{s}=2.5\right),[14,60]$ obtained a mean albedo of 0.27 which dropped as low 0.18 during a rain event. Differences aforementioned could be associated to the training systems, $r_{s} / h_{c}$ ratio and $f_{c}$, which affect the level of solar radiation reaching the soil surface.

Figure 4 shows the comparisons between observed and estimated values of the energy balance components at the time of satellite overpass. In this case, estimated values from METRIC were calculated using the calibrated functions of $L A I, z_{o m}$ and $G$. For the net radiation (squares) all points were over the 1:1 line with $R M S E$ and $M A E$ of 69.4 and $63 \mathrm{~W} \cdot \mathrm{m}^{-2}$, respectively. The t-test indicated that $R_{n_{-}} M / R_{n i}$ ratio ( $\left.b=1.11\right)$ was significantly different from unity (one) indicating that METRIC overestimated $R_{n}$ by approximately $11 \%$ (Table 4a). [78] showed values of RMSE and MAE equal to 51 and $25 \mathrm{~W} \cdot \mathrm{m}^{-2}$, respectively when a simplified residual SEB model was applied over a heterogeneous landscape in China. For corn, [28] reported that SEBAL overestimated $R_{n i}$ by $7 \%$ with a $R M S E=65 \mathrm{~W} \cdot \mathrm{m}^{-2}$. For sorghum and corn, [79] indicated that a two-source energy balance model underestimated $R_{n i}$ by about $4 \%$ with $R M S E=44.2 \mathrm{~W} \cdot \mathrm{m}^{-2}$.

The comparison between measured and modeled soil heat fluxes (diamonds) in Figure 4 shows that the points were grouped below the 1:1 line. In this case, the calibrated and original functions underestimated the instantaneous soil heat flux by about 17 and $5 \%$, respectively, with similar values of RMSE and MAE (Table 4). Similar studies carried out by [80] indicated that METRIC estimated $G_{i}$ with $R M S E=19 \mathrm{~W} \cdot \mathrm{m}^{-2}$ over a corn and soybean production region. [28] pointed out that SEBAL significantly overestimated $G_{i}$ for corn with $R M S E=79.8 \mathrm{~W} \cdot \mathrm{m}^{-2}$. Also, [81] estimated the soil heat fluxes with $R M S E=23 \mathrm{~W} \cdot \mathrm{m}^{-2}$ (error of $19 \%$ ) by the application of a remote sensing method over a heterogeneous surface. These authors suggested that errors could be attributable to the difference of spatial/temporal scales between satellite data and measurements.

The comparison between measured and estimated sensible heat fluxes during satellite overpasses (Figure 4-circles) shows that the points were over the 1:1 line. In this case, METRIC using the calibrated functions of $L A I$, zom and $G$ overestimates the instantaneous sensible heat fluxes by about $16 \%$ with RMSE, MAE and $d$ equal to $67 \mathrm{~W} \cdot \mathrm{m}^{-2}, 57 \mathrm{~W} \cdot \mathrm{m}^{-2}$ and 0.52 , respectively (Table. $4 \mathrm{a}$ ). When using the original function, METRIC overestimated the instantaneous sensible heat fluxes by about $13 \%$ $\left(R M S E=51 \mathrm{~W} \cdot \mathrm{m}^{-2} ; M A E=43 \mathrm{~W} \cdot \mathrm{m}^{-2}\right.$ and $\left.d=0.68\right)($ Table $4 \mathrm{~b})$. For corn and soybean, [80] indicated that METRIC tends to overestimate $H_{i}$ by about $80 \mathrm{~W} \cdot \mathrm{m}^{-2}$ with $R M S E=57 \mathrm{~W} \cdot \mathrm{m}^{-2}$. For corn, [28] indicated 
that instantaneous values of $H$ were underestimated by nearly $50 \%$. Over heterogeneous surfaces [78] indicated that the RMSE was $23 \mathrm{~W} \cdot \mathrm{m}^{-2}$ when a simplified residual SEB model was applied to estimate the sensible heat flux at the time of satellite overpass. According to [26,44,82], biases in the estimation of sensible heat fluxes are necessary because calculations (iterations) of $H_{-} M$ absorb the biases obtained previously in the computation of net radiation and soil heat fluxes. As a consequence the accuracy of the complete model in the estimation of $L E_{-} M$ strongly depends on the anchor pixel selection (end members), which determines the self-calibration of $H_{-} M$.

Figure 4. Comparisons at the time of satellite overpass between observed (axis $X$ ) and estimated (axis Y) values of net radiation $\left(R_{n}\right)$, soil heat flux $(G)$, sensible heat flux $(H)$, and latent heat flux $(L E)$ for a drip irrigated Merlot vineyard. Estimated values were obtained using METRIC with the calibrated functions. Subscript “ $i$ " denotes instantaneous values.

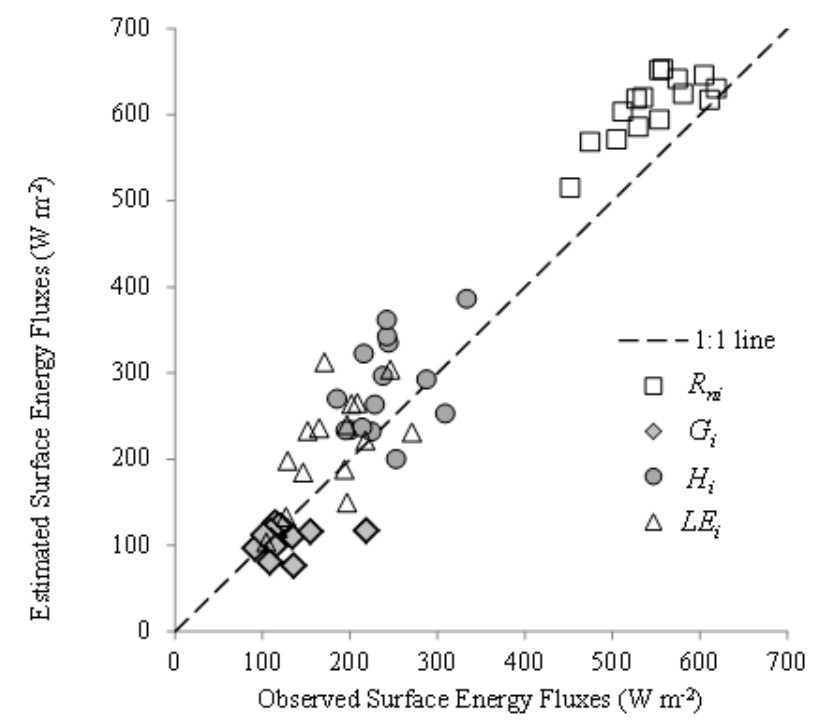

For the instantaneous latent heat flux, Figure 4 (triangles) depicts an equilibrated distribution of points around the 1:1 line with $R M S E$ and $M A E$ equal to 60 and $48 \mathrm{~W} \cdot \mathrm{m}^{-2}$, respectively (Table $4 \mathrm{a}$ ). When using the calibrated functions, the ratio of $L E_{-} M / L E_{i}$ was significantly different to the unity suggesting that instantaneous values of $L E_{-} M$ were overestimated by about in $17 \%$. When using original functions, METRIC significantly overestimated $(15 \%)$ the latent heat flux over the drip-irrigated vineyard with values of $R M S E, M A E$ and $d$ equal to $43,35 \mathrm{~W} \cdot \mathrm{m}^{-2}$ and 0.8 , respectively (Table 4b). For drip-irrigated vineyards, [83] found errors of $18 \%$ in the estimation of $L E_{i}$ when using a two-source energy balance (TSEB) model and Landsat scenes. In spite of this error, the TSEB model estimated daily $E T_{a}$ with $R M S E$ equal to $0.5 \mathrm{~mm} \cdot \mathrm{d}^{-1}$. In this regard, [32] observed that errors of $15 \%$ in the estimation of $L E_{i}$ produced an $E T_{a}$ overestimation of $9 \%$ with a $R M S E=0.62 \mathrm{~mm} \cdot \mathrm{d}^{-1}$ for the same Merlot vineyard. For fully covered crops, [28,80] found values of RMSE equal to 108 in corn and $55 \mathrm{~W} \cdot \mathrm{m}^{-2}$ in soybean, respectively. In general, the literature indicates that most of the remote sensing models applied over full or sparse canopies to estimate daily ETa presented errors between 0.5 and $0.8 \mathrm{~mm} \cdot \mathrm{d}^{-1}$ which are acceptable for irrigation management $[22,35,83]$.

METRIC with original (grey bars) and calibrated (white bars) functions both overestimated the instantaneous net radiation by about $63( \pm 30) \mathrm{W} \cdot \mathrm{m}^{-2}$ during the growing cycle (Figure $\left.5 \mathrm{a}\right)$. In this regard, the calibrated function of $L A I$ did not produce a significant effect on the computation of the 
surface emissivities, which are used by METRIC to estimate the outgoing long wave radiation and surface temperature [27]. Values of $H_{-} M, L E_{-} M$ and $G_{-} M$ using the calibrated functions showed biases of $35( \pm 50), 43( \pm 53)$ and $-15( \pm 31) \mathrm{W} \cdot \mathrm{m}^{-2}$, respectively; while those using the original functions presented biases of $29( \pm 33), 33( \pm 40)$ and $2( \pm 35) \mathrm{W} \cdot \mathrm{m}^{-2}$, respectively. These results suggest that errors in the estimation of $L A I_{-} M, z_{o m_{-} M}$ and $G_{-} M$ were balanced by the self-calibration of METRIC to estimate the instantaneous turbulent energy fluxes. Also, errors in estimations of $R_{n i}$ (Figure $5 \mathrm{a}$ ) and $G_{i}$ (Figure 5b) were typically balanced by bias in $H_{i}$ (Figure 5c). This buffer effect significantly influenced the estimations of latent heat fluxes at the time of satellite overpasses (Figure $5 \mathrm{~d}$ ).

Figure 5. Comparisons between the measured (black bars) and modeled values using METRIC with the original (grey bars) and calibrated (white bars) functions to estimate (a) net radiation $\left(R_{n i}\right)$; (b) soil heat flux $\left(G_{i}\right)$; (c) sensible heat flux $\left(H_{i}\right)$; and (d) latent heat flux $\left(L E_{i}\right)$ at the time of satellite overpass. Modeled values correspond to average from pixels inside the experimental plot. DOY is the day of the year. Subscript " $i$ " denotes instantaneous values.

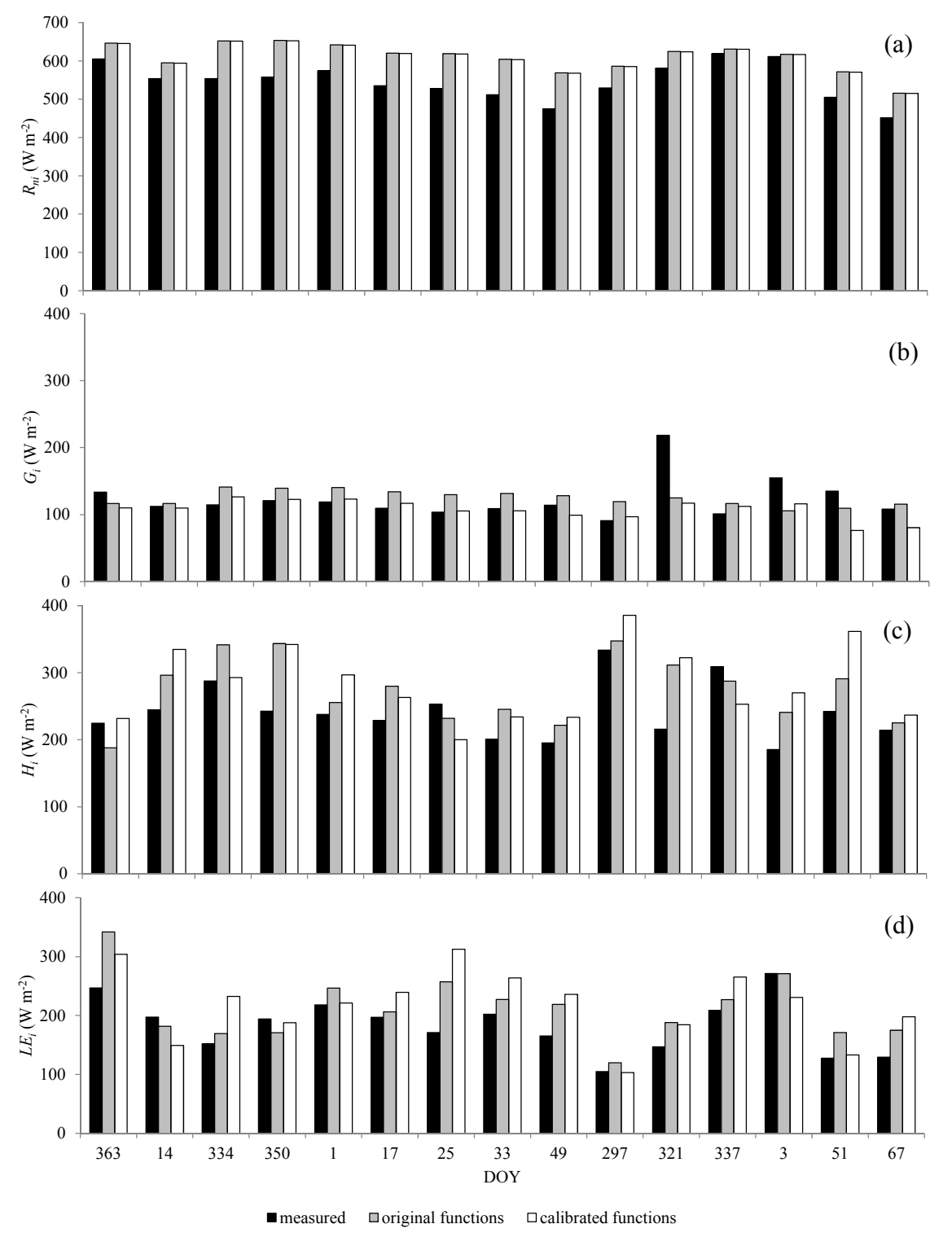


In this respect, sensitivity analysis studies applied to METRIC model indicated that variations on intermediate parameters (albedo, NDVI, LAI, G and roughness length) indirectly could affect the accuracy of $L E_{i}$ and subsequently $E T_{a}$ estimation [84,85], but the most important effect is attributable to the end member selection [82,85-89]. On this point, [90] indicated that the spatial distribution of $H_{i}$ in the image is based on $H_{i}$ estimation between two anchor pixels. So, if $L E_{i}$ at the anchor pixel is overestimated then $H$ will be underestimated throughout the satellite scene. On the contrary, if $L E_{i}$ is underestimated, $H_{i}$ will be overestimated. According to [27] the selection of the two "anchor" pixels requires knowledge, thoughtfulness and skill of the operator. These points have been indicated as controversial inside the ET research community because selection is subjective and depends of the ability of the operator in search and isolate of the most appropriates hot and cold pixels $[55,87,88]$.

\section{Spatial Variability of the Estimated Surface Energy Balance Components for the Complete Vineyard}

At the time of satellite overpass, Figure 6 shows the maps with the spatial variability of the satellite-based energy balance components estimated by METRIC using the calibrated functions. For the entire vineyard (97 ha), the maps were generated for the phenological stages of bud break (B), flowering (FL), fruit set (FS), veraison (V) and harvest (HA). Average values of $R_{n_{-}} M$ for the pixels inside the vineyard were $565( \pm 16), 565( \pm 16), 619( \pm 17), 632( \pm 17), 613( \pm 15)$ and $537( \pm 17) \mathrm{W} \cdot \mathrm{m}^{-2}$ for B, FL, FS, V and HA, respectively (Figure 6a-e). In this case, the coefficient of variation (less than 5\%) indicated that the spatial variability of $R_{n_{-}} M$ was not important. For B, FL, FS, V and HA $G_{-} M$ ranged between 50 and $190 \mathrm{~W} \cdot \mathrm{m}^{-2}$ with maximum and minimum values observed in veraison and fruit set, respectively (Figure $6 \mathrm{f}-\mathrm{j})$. Average values of $H_{-} M$ were $326( \pm 64), 311( \pm 78), 280( \pm 63)$, $281( \pm 59)$ and $296( \pm 44) \mathrm{W} \cdot \mathrm{m}^{-2}$ (Figure $\left.6 \mathrm{k}-\mathrm{o}\right)$ while those of $L E_{-} M$ were $135( \pm 86), 180( \pm 98)$, $223( \pm 81), 209( \pm 76)$ and $155( \pm 70) \mathrm{W} \cdot \mathrm{m}^{-2}$ (Figure $6 \mathrm{p}-\mathrm{t}$ ) for B, FL, FS, V and HA, respectively. In Figures 6k-o nearly a third of the complete vineyard can be clearly identified inside a dark blue area $\left(387 \mathrm{~W} \cdot \mathrm{m}^{-2}\right)$ corresponding to the old part of the vineyard where the training system shown more separated vines than the described for Merlot occupied in this study. The effect of distance inside this area presumably could increase the sensible heat flux due the bare soil beneath vines, considering that during this period the vineyard did not reach its complete foliage cover. Also, the highest and lowest values of $H_{-} M\left(400 \mathrm{~W} \cdot \mathrm{m}^{-2}\right)$ and $L E_{-} M\left(30 \mathrm{~W} \cdot \mathrm{m}^{-2}\right)$ were observed in areas without plants (bare soil and winery). The highest values of $R_{n_{-}} M\left(726 \mathrm{~W} \cdot \mathrm{m}^{-2}\right)$ and $L E_{-} M\left(300-500 \cdot \mathrm{W} \mathrm{m}{ }^{-2}\right)$ were observed in the vineyard contours reflecting the presence of trees, natural bushes and the influence of the "Lircay" River. The low spatial variability of $G_{-} \mathrm{M}, H_{-} M$ and $L E_{-} M$ observed for each phenological stage was associated with the uniform canopy shape of the vineyard where the values of $L A I$ and fractional cover $\left(f_{c}\right)$ were maintained between $0.8-1.2 \mathrm{~m}^{2} \cdot \mathrm{m}^{-2}$ and $0.28-0.31$, respectively, particularly after the full bloom soil surface was very dry and maintained free of weeds (cover crops) during October and March for all evaluation period in which rainfall was less than $3.0( \pm 2.4) \mathrm{mm}$. 
Figure 6. Averaged spatial distribution of net radiation $\left(R_{n_{-}} M\right)(\mathbf{a}-\mathbf{e})$; soil heat flux $\left(G_{-} M\right)$ $(\mathbf{f}-\mathbf{j})$; sensible heat flux $\left(H_{-} M\right)$ (Figure k-o); and latent heat flux $\left(L E_{-} M\right)(\mathbf{p}-\mathbf{t})$ over a drip-irrigated vineyard computed by the calibrated METRIC model. Column headers indicate the phenological stages. Averages were done combining data from the 2006-2007, 2007-2008 and 2008-2009 growing seasons; A panchromatic scene (u) from Landsat 7 (ETM+; DOY 17, 2008) is included as reference. The red square indicates the experimental plot location.
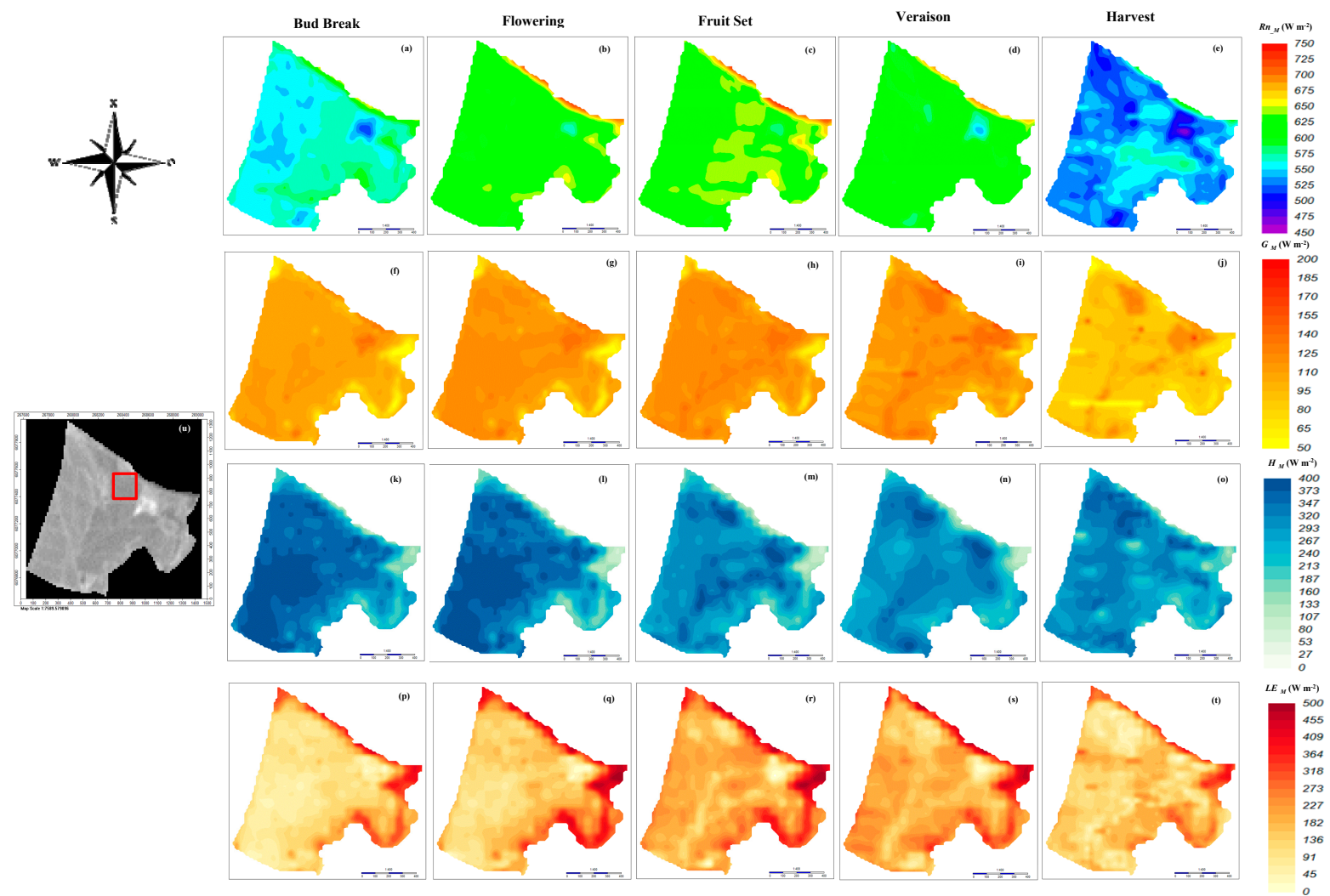

\section{Conclusions}

Empirical functions of METRIC to estimate $L A I, z_{o m}$ and $G_{i}$ were calibrated for a drip-irrigated vineyard under non-water stress (midday $\Psi x>-1.0 \mathrm{MPa}$ ). Results indicated that $L A I, z_{o m}$ and $G_{i}$ were estimated using the calibrated functions with errors of $4 \%, 2 \%$ and $17 \%$ while those were computed using the original functions with errors of $58 \%, 81 \%$, and $21 \%$, respectively. At the time of satellite overpass, the original METRIC underestimated the satellite-based albedo by about $21 \%$ and overestimated net radiation by $11 \%$. Using the calibrated functions, METRIC overestimated instantaneous latent and sensible heat fluxes by about $17 \%$ and $16 \%$, respectively. Using the original functions, it overestimated $L E$ and $H$ with errors of $15 \%$ and $13 \%$, respectively. Results of this research indicated that the calibration of $G_{i}, L A I$ and $z_{o m}$ did not produce significant effects on the estimation of the turbulent energy fluxes because of the self-calibration employed in the estimation of $H_{-} M$. Also, biases observed for instantaneous pixel-by-pixel values of $R_{n_{-}} M$ and $G_{-} M$, were presumably absorbed into $H_{-} M$ as a result of the self-calibration method of METRIC, which is highly dependent on the hot and cold pixels selection. Finally, future research needs to be performed considering a 
sensitivity analysis of intermediate variables and the use of an automatized method to optimize the selection of anchor pixels (wet and dry) at each scene.

\section{Acknowledgments}

This study was supported by the Chilean government through the projects FONDECYT (No. 1100714) and FONDEF (No. D10I1157), Universidad de Talca through the research program "Adaptation of Agriculture to Climate Change (A2C2)" and the project CONICYT Inserción de Capital Humano Avanzado en la Academia ( $\left.{ }^{\circ} 7912010010\right)$ (Universidad Católica del Maule). The following persons provided invaluable assistance in field measurements: Carlos Poblete, Christian Araya, María José Simeone, Francisco Jara and Leopoldo Fonseca from CITRA-Universidad de Talca; and Ricardo Marin and Alvaro Belmar from Jackson Wine Estates, Chile. We thank Edmond Khzam and Samuel Ortega Salazar for the help provided in the elaboration of maps and scripts. Finally, we thank Héctor Valdés-Gomez, Enrique Mundaca, Patrick Matzler, Jeissy Olguín; and the editor and anonymous reviewers for their valuable support, comments and suggestions to improve this manuscript.

\section{Author Contributions}

Marcos Carrasco-Benavides and Samuel Ortega-Farías conceived and designed this research and data analysis. They prepared the complete manuscript and consecutive revisions with contribution from all authors. It is important to indicate that Octavio Lagos, Jan Kleissl, Luis Morales and Ayse Kilic contributed extensively in results interpretation and discussions. Also, Octavio Lagos helped in the EC footprint analysis.

\section{Conflict of Interest}

The authors declare no conflict of interest.

\section{References}

1. Costa, J.M.; Ortuno, M.F.; Chaves, M.M. Deficit irrigation as a strategy to save water: Physiology and potential application to horticulture. J. Integr. Plant Biol. 2007, 49, 1421-1434.

2. Chaves, M.M.; Santos, T.P.; Souza, C.R.; Ortuño, M.F.; Rodrigues, M.L.; Lopes, C.M.; Maroco, J.P.; Pereira, J.S. Deficit irrigation in grapevine improves water-use efficiency while controlling vigour and production quality. Ann. Appl. Biol. 2007, 150, 237-252.

3. Fereres, E.; Soriano, M.A. Deficit irrigation for reducing agricultural water use. J. Exp. Bot. 2007, $58,147-159$.

4. Williams, L.E.; Matthews, M.A. Grapevine. In Irrigation of Agricultural Crops-Agronomy Monograph; Stewart, B.A., Nielson, D.R., Eds.; ASA-CSSA-SSSA: Madison, WI, USA, 1990; Volume 30, pp. 1019-1059.

5. Poblete-Echeverria, C.; Ortega-Farias, S. Estimation of actual evapotranspiration for a drip-irrigated Merlot vineyard using a three-source model. Irrig. Sci. 2009, 28, 65-78. 
6. Ferreyra, R.; Selles, V.; Peralta, J.; Burgos, L.; Valenzuela, J. Efectos de la restricción del riego en distintos períodos de desarrollo de la vid cv. Cabernet sauvignon sobre producción y calidad del vino. Agric. Tec. 2002, 62, 406-417.

7. Trambouze, W.; Bertuzzi, P.; Voltz, M. Comparison of methods for estimating actual evapotranspiration in a row-cropped vineyard. Agric. For. Meteorol. 1998, 91, 193-208.

8. Anderson, M.C.; Norman, J.M.; Mecikalski, J.R.; Otkin, J.A.; Kustas, W.P. A climatological study of evapotranspiration and moisture stress across the continental United States based on thermal remote sensing: 1. Model formulation. J. Geophys. Res. Atmos. 2007, 112, D10117.

9. Bastiaanssen, W.G.M.; Menenti, M.; Feddes, R.A.; Holtslag, A.A.M. A remote sensing surface energy balance algorithm for land (SEBAL) - 1. Formulation. J. Hydrol. 1998, 213, 198-212.

10. Verstraeten, W.W.; Veroustraete, F.; Feyen, J. Assessment of evapotranspiration and soil moisture content across different scales of observation. Sensors 2008, 8, 70-117.

11. Steiner, J.L.; Hatfield, J.L. Winds of change: A century of agroclimate research. Agron. J. 2008, 100, S132-S152.

12. Ortega-Farias, S.; Carrasco, M.; Olioso, A.; Acevedo, C.; Poblete, C. Latent heat flux over Cabernet Sauvignon vineyard using the Shuttleworth and Wallace model. Irrig. Sci. 2007, 25, 161-170.

13. Balbontin-Nesvara, C.; Calera-Belmonte, A.; Gonzalez-Piqueras, J.; Campos-Rodriguez, I.; Lopez-Gonzalez, M.L.; Torres-Prieto, E. Vineyard evapotranspiration measuraments in a semiarid environment: Eddy covariance and bowen ratio comparison. Agrociencia 2010, 45, 87-103.

14. Oliver, H.R.; Sene, K.J. Energy and water balances of developing vines. Agric. For. Meteorol. 1992, 61, 167-185.

15. Heilman, J.L.; McInnes, K.J.; Savage, M.J.; Gesch, R.W.; Lascano, R.J. Soil and canopy energy balances in a west Texas vineyard. Agric. For. Meteorol. 1994, 71, 99-114.

16. Kordova-Biezuner, L.; Mahrer, I.; Schwartz, C. Estimation of actual evapotranspiration from vineyard by utilizing eddy correlation method. Acta Hortic. 2000, 537, 167-175.

17. Campos, I.; Neale, C.M.U.; Calera, A.; Balbontín, C.; González-Piqueras, J. Assessing satellite-based basal crop coefficients for irrigated grapes (Vitis vinifera L.). Agric. Water Manag. 2010, 98, 45-54.

18. Kleissl, J.; Hong, S.H.; Hendrickx, J.M.H. New Mexico scintillometer network supporting remote sensing and hydrologic and meteorological models. Bull. Am. Meteorol. Soc. 2009, 90, doi:10.1175/2008BAMS2480.1.

19. Gowda, P.H.; Chávez, J.L.; Colaizzi, P.D.; Evett, S.R.; Howell, T.A.; Tolk, J.A. Remote sensing based energy balance algorithms for mapping ET: Current status and future challenges. Trans. ASABE 2007, 50, 1639-1644.

20. Allen, R.G.; Pereira, L.S.; Howell, T.A.; Jensen, M.E. Evapotranspiration information reporting: I. Factors governing measurement accuracy. Agric. Water Manag. 2011, 98, 899-920.

21. Courault, D.; Seguin, B.; Olioso, A. Review on estimation of evapotranspiration from remote sensing data: From empirical to numerical modeling approaches. Irrig. Drain. Syst. 2005, 19, 223-249.

22. Kalma, J.; McVicar, T.; McCabe, M. Estimating land surface evaporation: A review of methods using remotely sensed surface temperature data. Surv. Geophys. 2008, 29, 421-469. 
23. Santos, C.; Lorite, I.J.; Tasumi, M.; Allen, R.G.; Fereres, E. Performance assessment of an irrigation scheme using indicators determined with remote sensing techniques. Irrig. Sci. 2010, 28, 461-477.

24. Gowda, P.; Chavez, J.; Colaizzi, P.; Evett, S.; Howell, T.; Tolk, J. ET mapping for agricultural water management: Present status and challenges. Irrig. Sci. 2008, 26, 223-237.

25. Seguin, B.; Courault, D.; Guérif, M. Surface temperature and evapotranspiration: Application of local scale methods to regional scales using satellite data. Remote Sens. Environ. 1994, 49, 287-295.

26. Allen, R.G.; Tasumi, M.; Morse, A.; Trezza, R.; Wright, J.L.; Bastiaanssen, W.; Kramber, W.; Lorite, I.; Robison, C.W. Satellite-based energy balance for mapping evapotranspiration with internalized calibration (METRIC) applications. J. Irrig. Drain. Eng. 2007, 133, 395-406.

27. Allen, R.G.; Tasumi, M.; Trezza, R.; Kjaersgaard, J.H. METRIC-Mapping Evapotranspiration at High Resolution, Application Manual. Available online: http://www.kimberly.uidaho.edu/water/ metric/index.html (accessed on 30 May 2014).

28. Singh, R.K.; Irmak, A.; Irmak, S.; Martin, D.L. Application of SEBAL model for mapping evapotranspiration and estimating surface energy fluxes in South-Central Nebraska. J. Irrig. Drain. Eng. 2008, 134, 273-285.

29. ASCE-EWRI. The ASCE standarized reference evapotranspiration equation. In Report of the ASCE-EWRI Task Committee on Standarization of Reference Evapotranspiration; ASCE-EWRI: Kimberly, ID, USA, 2005; p. 147.

30. Allen, R.G.; Tasumi, M.; Trezza, R. Satellite-based energy balance for mapping evapotranspiration with internalized calibration (METRIC) Model. J. Irrig. Drain. Eng. 2007, 133, 380-394.

31. Chávez, J.; Neale, C.; Prueger, J.; Kustas, W. Daily evapotranspiration estimates from extrapolating instantaneous airborne remote sensing ET values. Irrig. Sci. 2008, 27, 67-81.

32. Carrasco-Benavides, M.; Ortega-Farías, S.; Lagos, L.O.; Kleissl, J.; Morales, L.; Poblete-Echeverría, C.; Allen, R. Crop coefficients and actual evapotranspiration of a drip-irrigated Merlot vineyard using multispectral satellite images. Irrig. Sci. 2012, 1-13.

33. Allen, R.; Irmak, A.; Trezza, R.; Hendrickx, J.M.H.; Bastiaanssen, W.; Kjaersgaard, J. Satellite-based ET estimation in agriculture using SEBAL and METRIC. Hydrol. Proc. 2011, 25, 4011-4027.

34. Tasumi, M.; Allen, R.G.; Trezza, R.; Wright, J.L. Satellite-based energy balance to assess within-population variance of crop coefficient curves. J. Irrig. Drain. Eng. 2005, 131, 94-109.

35. Galleguillos, M.; Jacob, F.; Prévot, L.; French, A.; Lagacherie, P. Comparison of two temperature differencing methods to estimate daily evapotranspiration over a Mediterranean vineyard watershed from ASTER data. Remote Sens. Environ. 2011, 115, 1326-1340.

36. Galleguillos, M.; Jacob, F.; Prevot, L.; Lagacherie, P.; Liang, S.L. Mapping daily evapotranspiration over a mediterranean vineyard watershed. IEEE Geosci. Remote Sens. Lett. 2011, 8, 168-172.

37. Bastiaanssen, W.G.M.; Pelgrum, H.; Soppe, R.W.O.; Allen, R.G.; Thoreson, B.P.; Teixeira, A.H. Thermal-infrared technology for local and regional scale irrigation analyses in horticultural systems. Acta Hortic. 2008, 793, 33-46. 
38. Santos, C.; Lorite, I.J.; Allen, R.G.; Tasumi, M. Aerodynamic parameterization of the satellite-based energy balance (METRIC) model for ET estimation in rainfed olive orchards of Andalusia, Spain. Water Resour. Manag. 2012, 26, 3267-3283.

39. Teixeira, A.H.; Bastiaanssen, W.G.M.; Ahmad, M.D.; Bos, M.G. Reviewing SEBAL input parameters for assessing evapotranspiration and water productivity for the Low-Middle Sao Francisco River basin, Brazil Part B: Application to the regional scale. Agric. For. Meteorol. 2009, 149, 477-490.

40. Ortega-Farias, S.; Poblete-Echeverría, C.; Brisson, N. Parameterization of a two-layer model for estimating vineyard evapotranspiration using meteorological measurements. Agric. For. Meteorol. 2010, 150, 276-286.

41. Tasumi, M.; Allen, R.G.; Trezza, R. At-surface reflectance and albedo from satellite for operational calculation of land surface energy balance. J. Hydrol. Eng. 2008, 13, 51-63.

42. Tasumi, M. Progress in Operational Estimation of Regional Evapotranspiration Using Satellite Imagery. Ph.D. Thesis, University of Idaho, Moscow, ID, USA, 2003.

43. Basso, B.; Cammarano, D.; DeVita, P. Remotely sensed vegetation indices: Theory and applications for crop management. Riv. Ital. Agrometeorol. 2004, 1, 36-53.

44. Kjaersgaard, J.H.; Allen, R.G.; Garcia, M.; Kramber, W.; Trezza, R. Automated selection of anchor pixels for landsat based evapotranspiration estimation. In World Environmental and Water Resources Congress 2009 Great Rivers; ASCE, Ed.; ASCE: Kansas City, MO, USA, 2009; pp. $4400-4410$.

45. Coombe, B.G. Growth Stages of the Grapevine: Adoption of a system for identifying grapevine growth stages. Aust. J. Grape Wine Res. 1995, 1, 104-110.

46. Li, S.; Tong, L.; Li, F.; Zhang, L.; Zhang, B.; Kang, S. Variability in energy partitioning and resistance parameters for a vineyard in northwest China. Agric. Water Manag. 2009, 96, 955-962.

47. Webb, E.; Pearman, G.; Leuning, R. Correction of flux measurements for density effects due to heat and water vapour transfer Q. J. R. Meteorol. Soc. 1980, 106, 85-100.

48. Schotanus, P.; Nieuwstadt, F.T.M.; de Bruin, H.A.R. Temperature measurement with a sonic anemometer and its application to heat and moisture fluctuations. Bound. Layer Meteorol. 1983, 26, 81-93.

49. Wilczak, J.; Oncley, S.; Stage, S. Sonic anemometer tilt correction algorithms. Bound. Layer Meteorol. 2001, 99, 127-150.

50. Twine, T.E.; Kustas, W.P.; Norman, J.M.; Cook, D.R.; Houser, P.R.; Meyers, T.P.; Prueger, J.H.; Starks, P.J.; Wesely, M.L. Correcting eddy-covariance flux underestimates over a grassland. Agric. For. Meteorol. 2000, 103, 279-300.

51. Chávez, J.; Howell, T.; Copeland, K. Evaluating eddy covariance cotton ET measurements in an advective environment with large weighing lysimeters. Irrig. Sci. 2009, 28, 35-50.

52. Poblete-Echeverría, C.; Ortega-Farias, S. Calibration and validation of a remote sensing algorithm to estimate energy balance components and daily actual evapotranspiration over a drip-irrigated Merlot vineyard. Irrig. Sci. 2012, 30, 537-553.

53. Earth Resources Observation and Science Center (EROS). USGS Global Visualization Viewer Available online: http://glovis.usgs.gov/ (accessed on 1 September 2010). 
54. Earth Resources Observation and Science Center (EROS). Landsat Processing Details. Available online: http://landsat.usgs.gov/Landsat_Processing_Details.php (accessed on 22 July 2014).

55. Cuenca, R.; Ciotti, S.; Hagimoto, Y. Application of landsat to evaluate effects of irrigation forbearance. Remote Sens. 2013, 5, 3776-3802.

56. Allen, R.G.; Pereira, L.S.; Raes, D.; Smith, M. FAO irrigation and drainage paper No. 56. In Crop Evapotranspiration Guidelines for Computing Crop Water Requirements; Food and Agriculture Organization of the United Nations: Rome, Italy, 1998; p. 298.

57. Folhes, M.T.; Renno, C.D.; Soares, J.V. Remote sensing for irrigation water management in the semi-arid Northeast of Brazil. Agric. Water Manag. 2009, 96, 1398-1408.

58. Fuentes, S.; Poblete-Echeverría, C.; Ortega-Farias, S.; Tyerman, S.; de Bei, R. Automated estimation of leaf area index from grapevine canopies using cover photography, video and computational analysis methods. Aust. J. Grape Wine Res. 2014, 20, 465-473.

59. Yang, R.C.; Kozak, A.; Smith, J.H.G. The potential of Weibull-type functions as flexible growth curves. Can. J. For. Res. 1978, 8, 424-431.

60. Sene, K.J. Parameterisations for energy transfers from a sparse vine crop. Agric. For. Meteorol. 1994, 71, 1-18.

61. Singh, R.K.; Irmak, A. Estimation of crop coefficients using satellite remote sensing. J. Irrig. Drain. Eng. ASCE 2009, 135, 597-608.

62. Mayer, D.G.; Butler, D.G. Statistical validation. Ecol. Model. 1993, 68, 21-32.

63. Willmott, C.J. On the validation of models. Phys. Geogr. 1981, 2, 184-194.

64. Willmott, C.J.; Ackleson, S.G.; Davis, R.E.; Feddema, J.J.; Klink, K.M.; Legates, D.R.; O'donnell, J.; Rowe, C.M. Statistics for the evaluation and comparison of models. J. Geophys. Res. 1985, 90, 8995-9005.

65. Williams, L.E.; Trout, T.J. Relationships among vine- and soil-based measures of water status in a thompson seedless vineyard in response to high-frequency drip irrigation. Am. J. Enol. Vitic. 2005, 56, 357-366.

66. Choné, X.; Van Leeuwen, C.; Dubourdieu, D.; Gaudillère, J.P. Stem water potential is a sensitive indicator of Grapevine water status. Ann. Bot. 2001, 87, 477-483.

67. Ferreyra, R.; Selles, G.; Peralta, J.; Burgos, L.; Valenzuela, J. Efectos de la Restricción del Riego En Distintos Períodos de Desarrollo de la Vid cv. Cabernet Sauvignon Sobre Producción y Calidad del Vino. Agric. Tec. 2002, 62, 406-417.

68. Pieri, P.; Gaudillere, J.P. Sensitivity to training system parameters and soil surface albedo of solar radiation intercepted by vine rows. Vitis $\mathbf{2 0 0 3}, 42,77-82$.

69. Yunusa, I.A.M.; Walker, R.R.; Lu, P. Evapotranspiration components from energy balance, sapflow and microlysimetry techniques for an irrigated vineyard in inland Australia. Agric. For. Meteorol. 2004, 127, 93-107.

70. Macedo Pezzopane, J.R.; Pedro Júnior, M.J. Balanço de energia em vinhedo de "Niagara Rosada". Bragantia 2003, 62, 155-161.

71. Teixeira, A.H.D.C.; Bastiaanssen, W.G.M.; Bassoi, L.H. Crop water parameters of irrigated wine and table grapes to support water productivity analysis in the São Francisco river basin, Brazil. Agric. Water Manag. 2007, 94, 31-42. 
72. Carrasco, M.; Ortega-Farias, S. Evaluation of a model to simulate net radiation over a vineyard cv. Cabernet Sauvignon. Chil. J. Agric. Res. 2008, 68, 156-165.

73. Green, A.; Green, S.; Caspari, H. Latent heat flux from a vineyard using scintillometry. Terr. Atmos. Ocean. Sci. 2000, 2, 525-542.

74. Heilman, J.L.; McInnes, K.J.; Gesch, R.W.; Lascano, R.J.; Savage, M.J. Effects of trellising on the energy balance of a vineyard. Agric. For. Meteorol. 1996, 81, 79-93.

75. Cammalleri, C.; Ciraolo, G.; La Loggia, G.; Maltese, A. Daily evapotranspiration assessment by means of residual surface energy balance modeling: A critical analysis under a wide range of water availability. J. Hydrol. 2012, 452-453, 119-129.

76. Johnson, L.F.; Roczen, D.E.; Youkhana, S.K.; Nemani, R.R.; Bosch, D.F. Mapping vineyard leaf area with multispectral satellite imagery. Comput. Electron. Agric. 2003, 38, 33-44.

77. Hall, A.; Louis, J.P.; Lamb, D.W. Low-resolution remotely sensed images of winegrape vineyards map spatial variability in planimetric canopy area instead of leaf area index. Aust. J. Grape Wine Res. 2008, 14, 9-17.

78. Liu, S.; Lu, L.; Mao, D.; Jia, L. Evaluating parameterizations of aerodynamic resistance to heat transfer using field measurements. Hydrol. Earth Syst. Sci. 2007, 11, 769-783.

79. Chávez, J.; Gowda, P.; Howell, T.; Neale, C.; Copeland, K. Estimating hourly crop ET using a two-source energy balance model and multispectral airborne imagery. Irrig. Sci. 2009, 28, 79-91.

80. Choi, M.; Kustas, W.P.; Anderson, M.C.; Allen, R.G.; Li, F.; Kjaersgaard, J.H. An intercomparison of three remote sensing-based surface energy balance algorithms over a corn and soybean production region (Iowa, U.S.) during SMACEX. Agric. For. Meteorol. 2009, 149, 2082-2097.

81. Shaomin, L.; Guang, H.; Li, L.; Defa, M. Estimation of regional evapotranspiration by TM/ETM+ data over heterogeneous surfaces. Am. Soc. Photogramm. Remote Sens. 2007, 73, 1169-1178.

82. Wang, J.; Sammis, T.W.; Gutschick, V.P.; Gebremichael, M.; Miller, D.R. Sensitivity analysis of the surface energy balance algorithm for land (SEBAL). Trans. ASABE 2009, 52, 801-811.

83. González-Dugo, M.P.; González-Piqueras, J.; Campos, I.; Andréu, A.; Balbontín, C.; Calera, A. Evapotranspiration monitoring in a vineyard using satellite-based thermal remote sensing. Proc. SPIE 2012, 8531, doi:10.1117/12.974731.

84. Lu, J.; Tang, R.; Tang, H.; Li, Z.-L. Derivation of daily evaporative fraction based on temporal variations in surface temperature, air temperature, and net radiation. Remote Sens. 2013, 5, 5369-5396.

85. Mokhtari, M.H.; Ahmad, B.; Hoveidi, H.; Busu, I. Sensitivity anaysis of METRIC-based evapotranspiration algorithm. Int. J. Environ. Res. 2013, 72, 407-422.

86. Wang, X.-G.; Wang, W.; Huang, D.; Yong, B.; Chen, X. Modifying SEBAL model based on the trapezoidal relationship between land surface temperature and vegetation index for actual evapotranspiration estimation. Remote Sens. 2014, 6, 5909-5937.

87. Long, D.; Singh, V.P. A modified surface energy balance algorithm for land (M-SEBAL) based on a trapezoidal framework. Water Resour. Res. 2012, 48, doi:0.1029/2011WR010607.

88. Long, D.; Singh, V.P. Assessing the impact of end-member selection on the accuracy of satellite-based spatial variability models for actual evapotranspiration estimation. Water Resour. Res.

2013, 49, 2601-2618. 
89. Long, D.; Singh, V.P. Integration of the GG model with SEBAL to produce time series of evapotranspiration of high spatial resolution at watershed scales. J. Geophys. Res. Atmos. 2010, 115, doi:10.1029/2010JD014092.

90. Singh, R.K.; Irmak, A. Treatment of anchor pixels in the METRIC model for improved estimation of sensible and latent heat fluxes. Hydrol. Sci. J. 2011, 56, 895-906.

(C) 2014 by the authors; licensee MDPI, Basel, Switzerland. This article is an open access article distributed under the terms and conditions of the Creative Commons Attribution license (http://creativecommons.org/licenses/by/4.0/). 